(C) 2021, The Authors. Published by Elsevier Inc. and Fass Inc. on behalf of the American Dairy Science Association ${ }^{\circledR}$. This is an open access article under the CC BY-NC-ND license (http://creativecommons.org/licenses/by-nc-nd/4.0/).

\title{
Invited review: A 2020 perspective on pasture-based dairy systems and products
}

\author{
Alice Moscovici Joubran, ${ }^{1,2}$ @ Karina M. Pierce, ${ }^{1,2} \odot$ Niamh Garvey, ${ }^{1}$ Laurence Shalloo, ${ }^{3} \odot$ \\ and Tom F. O'Callaghan ${ }^{1,4,5 *}$ \\ ${ }^{1}$ Food For Health Ireland, University College Dublin, Dublin D04 V1W8, Ireland \\ ${ }^{2}$ School of Agriculture and Food Science, University College Dublin, Dublin D04 V1W8, Ireland \\ ${ }^{3}$ Teagasc Animal and Grassland Research and Innovation Centre, Moorepark, Fermoy, Co. Cork P61 C996, Ireland \\ ${ }^{4}$ Teagasc Food Research, Moorepark, Fermoy, Co. Cork P61 C996, Ireland \\ ${ }^{5}$ School of Food and Nutritional Sciences, University College Cork, Cork T12 K8AF, Ireland
}

\begin{abstract}
Grazing pasture is the basis for dairy production systems in regions with temperate climates, such as in Ireland, New Zealand, parts of Australia, the United States, and Europe. Milk and dairy products from cows on pasture-based farms predominantly consuming fresh grazed grass (typically classified as "grass-fed" milk) have been previously shown to possess a different nutrient profile, with potential nutritional benefits, compared with conventional milk derived from total mixed ration. Moreover, pasture-based production systems are considered more environmentally and animal welfare friendly by consumers. As such, there is significant potential for market capitalization on grass-fed dairy products. As competition in this space increases, the regulations of what constitutes as grass-fed vary between different regions of the world. With this in mind, there is a need for clear and independently accredited grass-fed standards, defining the grass-fed criteria for labeling of products as such, subsequently increasing the clarity and confidence for the consumer. This review outlines the numerous effects of pasture production systems on dairy product composition, nutritional profile, and sustainability, and highlights potential future methods for authentication.
\end{abstract}

Key words: grass-fed, dairy, pasture, animal welfare, sustainability

\section{INTRODUCTION}

The world's population is predicted to reach 10.4 billion by 2067, diminishing the arable land available for food production, and therefore, posing serious challenges to meet growing food supply demands (Britt et

Received October 13, 2020.

Accepted March 2, 2021.

*Corresponding author: tom_ocallaghan@ucc.ie al., 2018). Dairy products are highly nutritious and their inclusion in the human diet provides EAA and micronutrients otherwise lacking in typical plant-based foods (Haug et al., 2007). The annual consumption of dairy products worldwide averages $\sim 87 \mathrm{~kg}$ per person, with $82.4 \%$ of the world's milk produced by dairy cows (Britt et al., 2018). Primary production strategies for dairy varies across the world dependent on a number factors such as land availability, climate, infrastructure, and so on. However, in recent years the increased prevalence of "grass-fed" milk labeling on market shelves has been prompted by interest from consumers, often demanding a premium price as a result of certain perceptions of such products related to health and environmental footprint considerations. Indeed, Stampa et al. (2020) reported that there are a variety of consumer demographics willing to pay a premium price for pasture-raised attributes, even on top of an already premium organic price. However, the authors also reported that consumer knowledge around the subject is low and there is confusion around the terminology used, mistaking the production system behind pasture-raised products for organic or conventional, with important differences that will be discussed later. It could also be argued that there is some ambiguity around the terminology of "grass-fed" versus "pasture based," whereby "grass-fed" is an indication of the proportion of grass in fresh or ensiled form in the diet and "pasture based" implies cows are outdoors grazing fresh grass. Milk production worldwide is expected to grow at $1.7 \%$ per annum over the next decade and reach 981 Mt by 2028, faster than most other main agricultural commodities (OECD-FAO, 2019). Due to population growth, urbanization, rising incomes, and dietary changes, the demand for milk and dairy products in developing countries is growing. This trend is especially evident in East and Southeast Asia, particularly in densely populated countries such as China, Indonesia, and Vietnam. In these areas as well as in Africa and the 
Middle East, consumption is expected to grow faster than domestic production, resulting in a substantial increase in dairy trade across borders (FAO, 2019).

Recent trends would suggest that the dairy industry is in decline in Australia, with national milk production now at 8.8 billion liters, down more than $10 \%$ since 2008-2009. The number of dairy farmers has also decreased from 8,000 to just over 5,000 over the same period (Australian Bureau of Statistics, 2020). The vast majority of Australian dairies are in coastal regions, taking advantage of the higher rainfall these areas experience, and as a consequence, greater grass production. Approximately 60 to $65 \%$ of a cow's diet comes from fresh grazed grass averaged over a year (Dairy Australia, 2020).

However, significant changes in the feeding systems have also occurred in Australia, with a reduction in the pasture intake of dairy cows and an increase in concentrate feeding, averaging $1.6 \mathrm{t}$ of $\mathrm{DM} /$ cow annually, having increased from $0.7 \mathrm{t}$ of $\mathrm{DM} /$ cow $25 \mathrm{yr}$ ago (Dharma et al., 2012). These changes have occurred due to the relatively low cost of cereal grain compared with other energy-based supplements, and motivation to increase production per cow and per hectare (Jacobs, 2014). An increased incidence of drought conditions has been affecting multiple dairy-producing regions, with farmers contending with poor pasture growth, high feed prices, and reduced water allocations. In 2018-2019, this saw the cost of production grow significantly across all regions and contributed to the decline in milk production. Under these conditions, many farmers opted to milk a lesser portion of the herd, de-stock, or even exit the industry. Research by Wales and Kolver (2017a) showed that $64 \%$ of Australian dairy farmers fed moderate to high amounts of concentrate $(>1 \mathrm{t} /$ cow per year), an increase of $10 \%$ compared with the results from the 2010-2011 survey. Farms where grazed pasture was supplemented with partial mixed ration offered on a feed pad comprised $12 \%$ of dairy farms. At a regional level in Australia, approximately $10 \%$ of dairy farms in Tasmania and Gippsland in Victoria do not feed any grain, which contrasts with the remaining regions where this number is less than $4 \%$.

In the United States, the emphasis is on TMR with significant reliance on cereal grain-based concentrate feeds (Wilkinson and Lee, 2018). However, there is great variation in herd size within and between regions. There is a resurgence of interest in pasture-based dairy farming systems in different areas across the United States. This can be attributed in part to prevailing trends in the dairy industry.

Since the abolishment of European Union milk quotas in 2015, there has been an increase of $4.5 \%$ in the production of raw milk on EU farms, from 164.8 million tonnes in 2014 to 172.2 million tonnes in 2018 (Eurostat, 2019). This rapid expansion brought many challenges, including maintaining animal welfare, as well as adhering to stricter targets for greenhouse gas emissions and water quality. In Ireland, one of the benefits arising from the dramatic changes and expansion of dairy farms has been improved technical efficiency and profitability, particularly for pasture-based systems (Kelly et al., 2020), with cost of milk production decreasing across Europe. As an example, Ireland's dairy industry is associated with grass growth throughout most of the year due to the favorable conditions of a temperate climate, abundant rainfall, and fertile soils (Hurtado-Uria et al., 2013), as such reducing requirements for supplemental concentrates in the diet and costs associated with these. With that, the image of grazing cows is synonymous with Irish dairy, where pasture is utilized as the main, low-cost feeding source (Finneran et al., 2012). Typically in Ireland, the majority of herd calving takes place synchronously in the spring time between January and April (ICBF, 2020) after which cows move out on pasture and begin their lactation, typically grazing for more than $240 \mathrm{~d}$ per year (O'Brien et al., 2018). As a result Ireland practices a seasonal milk production system from February to November/December, where milk supply peaks in May to June followed by a steady decrease until the end of lactation (O'Brien et al., 1999c). The system focuses on matching feed supply and demand through management of stocking rate, calving date, and the levels of supplementary feeds offered (Shalloo et al., 2014). In addition to milk's traditional nutritional value (fat and protein content), consumer trends of preference have evolved to include other considerations such as a product's environmental footprint, sustainability, and broader nutritional benefits and sensory characteristics (Haas et al., 2019; Stampa et al., 2020). As such there are further market opportunities for pasture-based dairy farmers and dairy manufacturers. With this in mind, the purpose of this review is to examine current literature on the effect of pasture-based feeding on the composition and quality of grass-fed milk and dairy products and attributes of these systems considering animal welfare, sustainability, and potential tools for authentication in the future.

\section{DAIRY COW FEEDING SYSTEMS}

The composition of bovine milk, which contains mainly water $(\sim 87 \%)$, lactose $(\sim 4.8 \%)$, fat $(\sim 4.2 \%)$, and protein $(\sim 3.5 \%)$, is affected by numerous factors, including cow breed, genetics, age, diet, and stage of lactation. Cow feeding system has been identified as an important factor that can modify the nutritional 
profile of milk (Linn, 1988; Auldist and Hubble, 1998; Mackle et al., 1999; O'Brien et al., 1999b,c; Auldist et al., 2000a,b; Moran, 2005; Fox et al., 2015).

\section{Pasture}

Traditionally, grazing on fresh pasture was the primary feeding system for dairy cows. While some countries have migrated away from pasture feeding to more intensive TMR systems, which offer greater control of the cow diet to maximize production, countries such as Ireland and New Zealand with a temperate climate extensively practice pasture-based systems that are considered cost efficient, especially in regions which allow for ample grass growth (Roche, 2007; O'Neill et al., 2011). Nevertheless, globally it is estimated that only 10 to $15 \%$ of milk production is based on grazing systems (Shalloo et al., 2018) and in Europe the levels of grazing are declining (Hennessey et al., 2020). A strong inverse relationship has been demonstrated between cost of production per liter and proportion of grazed grass in the dairy cow diet (Kelly et al., 2020). In Ireland, each additional tonne of pasture DM utilized per hectare increased the net profit by $€ 173$ (Hanrahan et al., 2018; Kelly et al., 2020). Some studies have demonstrated benefits of inclusion of white clover in pasture, due to its ability to reduce nitrous oxide emissions, fix atmospheric nitrogen, and reduce carbon footprint (Ledgard et al., 2009; Yan et al., 2013). A key focus of pasture management centers on maximizing grass utilization through optimal grassland management, while allowing individual cows to express their individual potential. For example, increasing pasture allowance by $32 \%$ during early or mid lactation was demonstrated to result in an increased milk yield as well as total protein and casein concentrations. Increasing individual cow allocation would allow for increased cow performance but could result in poor grass utilization on a per hectare basis, as McCarthy et al. (2011) demonstrated, that whereas milk production per cow is reduced as stocking rate increases, a strong positive relationship exists between stocking rate and milk production per hectare. To meet the dietary requirements of cows when grass growth is limited in temperate countries, the diet is usually supplemented with concentrates in particular after calving and toward the end of lactation (Dillon et al., 1997; McEvoy et al., 2008), and intake potential is low in order for the cows' feed and energy requirements to be met.

\section{TMR and Partial Mixed Ration Systems}

In the United States, most of Europe, and parts of the Southern Hemisphere, TMR is widely used as the prevailing feeding system, where cows are maintained indoors year-round. This is usually also coupled with specialist herd management strategies, utilizing yearround calving, diminishing the effects of seasonality on milk composition and functionality (Schingoethe, 2017). Total mixed ration is essentially a nutritionally formulated feed mix, combining feeds formulated to a specific nutrient content. Such feeds may contain forage (grass silage, hay, or straw), grains (corn, oats, wheat, and barley), protein feeds (soybean, cottonseed, linseed, and groundnut), minerals, vitamins, feed additives, and by-products. The advantages of indoor TMR systems include protection of cows from environmental extremes and a constant and consistent feed composition, easier recording of feed intake and regulation of DMI, and higher milk yield (Kolver and Muller, 1998; McAuliffe et al., 2016). Total mixed ration can also be easily offered to cows in confinement throughout the year, in line with the increase in herd size and demand for higher milk yield. As such, housing cows indoors has become more popular in certain regions of the world (Elgersma, 2015). An alternative to TMR is partial mixed ration, which is basically a TMR offered on a feed pad between bouts of grazing at pasture (Bargo et al., 2002).

The choice of supplement type may have different effects on the composition of milk produced. Supplementing grazing dairy cows with fodder beet in early lactation was demonstrated to increase saturated and medium-chain fatty acid content, but did not alter milk production (Fleming et al., 2018). A similar study, which looked at supplements given to cows grazing a restricted pasture allowance, found that a mixed ration supplement containing milled barley grain, alfalfa hay, corn silage, and crushed corn grain increased milk fat yield with marginal milk production responses compared with pasture forage alone or a combination of milled barley grain and pasture forage (Auldist et al., 2013). Another study compared 4 different supplemental feeds for pasture-based cows: $16 \% \mathrm{CP}$ parlor concentrate, palm kernel plus parlor concentrate, soy hulls plus parlor concentrate, and molassed beet pulp plus parlor concentrate. This study demonstrated that supplement type significantly modified the size of native casein micelles, fatty acid composition and nutritional indices, sensory volatile profile, as well as acid gelation properties of raw milks (O'Callaghan et al., 2019). Oliveira et al. (2015) also reported that the addition of palm kernel cake to the cow diet had a negative effect on the fatty acid profile of milk. Stage of lactation also has a significant effect on milk composition. O'Callaghan et al. (2016b) demonstrated that significant changes occur to milk composition throughout lactation as cows progress through early, mid, and late stages in a spring 
calving system regardless of whether the diet is pasture or TMR based.

\section{CURRENT KNOWLEDGE ON GRASS-FED PRODUCTS-COMPOSITIONAL, NUTRITIONAL, SENSORY, AND FUNCTIONAL PROPERTIES}

Numerous research studies have evaluated the effect of pasture feeding on the composition, sensory, and functional characteristics of milk and other dairy products, such as cheese and butter. The existing literature commonly reports changes in milk yield and composition, while some researchers have also highlighted sensory attributes and functional properties related to milk from pasture-based feeding systems. Before considering any potential nutritional benefits associated with pasture-derived products which arise from compositional modifications, it is important to understand how different milk components can contribute toward health and well-being.

\section{Milk Fat}

Milk and dairy products represent complex food matrices that are viable sources of essential nutrients including CLA, oleic acid, n-3 fatty acids, short- and medium-chain fatty acids, vitamins and minerals, as well as other bioactive compounds that may have beneficial health effects (Haug et al., 2007). A significant amount of these essential nutrients is supplied by daily intake of $500 \mathrm{~mL}$ of milk or an equivalent amount of other dairy products (Haug et al., 2007). The consumption of milk and dairy products has been linked to positive health outcomes, such as reduced risk of type 2 diabetes, reduced risk of obesity in children, and improved body composition in adults (Lamarche et al., 2016; Lovegrove and Givens, 2016; Thorning et al., 2016). Consuming full-fat or fermented milk has been shown to increase gastric emptying time, which could be beneficial for glycemic response and even appetite regulation (Haug et al., 2007). On the other hand, refraining from dairy products without a suitable substitution increases the risk of developing deficiencies such as calcium, vitamin D, and long chain n-3 (Craig, 2009; Clarys et al., 2014; Beto, 2015).

Although saturated fat has been associated with negative health outcomes in the past, particularly cardiovascular disease (Pfeuffer and Schrezenmeir, 2000), a neutral or inverse association was demonstrated for SFA in dairy products (Haug et al., 2007; Siri-Tarino et al., 2015; Lamarche et al., 2016; Lovegrove and Givens, 2016; Thorning et al., 2016). Particularly, other indices such as levels of n-6 and n-3 fatty acids, thrombogenic index, and atherogenic index could be taken into account when evaluating health effects of fat (Ulbricht and Southgate, 1991).

Omega-6 (n-6) and n-3 fatty acids are essential PUFA that are not synthesized by the body, classified according to the final double bond location in relation to the terminal methyl end (Wall et al., 2010). Eicosanoids derived from n-6 and n-3 are known to participate in the regulation of inflammation; therefore, their dietary ratio has gained much interest as a nutritional biomarker (Patterson et al., 2012; Benbrook et al., 2013). Although the optimal ratio of n-6:n-3 was defined as lower than $4: 1$, the increased intake of $n-6$ in the Western diet results in an estimated ratio of 15:1 to 16.7:1 (Lee et al., 2019). A specific fatty acid that has gained considerable interest in recent years is CLA, which possesses various potent bioactivities such as antihypertensive, antidiabetic, antiobesity, and anticarcinogenic functions (Koba and Yanagita, 2014). Conjugated linoleic acid isomers have been shown to reduce chemically induced tumors in the mammary gland, skin, colon, and forestomach in animal studies (Kelley et al., 2007). The cis-9,trans-11 isomer of CLA known as rumenic acid is a distinct feature of ruminant milk, biohydrogenated from linoleic and linolenic acids originating in the feed and enzymatically produced from vaccenic acid by desaturase in the mammary tissue (Mohammed et al., 2009; Elgersma, 2015). Sheep cheese naturally enriched with $\alpha$-linolenic acid (ALA), CLA, and vaccenic acid given to adults with mild hypercholesterolemia was found to significantly increase the plasma concentrations of CLA, ALA, and eicosapentaenoic acid (EPA) as well as decreased low-density lipoprotein cholesterol (Pintus et al., 2013). Milk fat is also known to contain important n-3 fatty acids, including ALA, EPA, and docosahexaenoic acid, which possess an array of health benefits. Due to their vital contribution to proper fetal development, these fatty acids are particularly important for pregnant and lactating women. In addition, EPA and docosahexaenoic acid have been shown to improve numerous physiological and health conditions such as inflammation, peripheral artery disease, and weight management, and demonstrated promising results in cognitive function in those with very mild Alzheimer's disease (Palmquist, 2009; Swanson et al., 2012). Other milk fat components (e.g., bovine milk fat globule membrane and its phospholipids) have been shown to have antibacterial, anticancer, and cholesterolemia-lowering properties (Spitsberg, 2005). Milk fat also contains numerous fat-soluble antioxidants, namely $\beta$-carotene, retinol, and tocopherol, which are important for the pro- and antioxidant balance in the human body; $\beta$-carotene also functions as a precursor 
for the synthesis of vitamin A, whereas retinol and tocopherol function as vitamin A and E, respectively (de la Torre et al., 2018).

\section{Milk Protein}

Protein originating from animal products is considered of high quality due to its content of EAA and NEAA, and other micronutrients (Broderick, 2017). Milk contains $\sim 3.5 \mathrm{~g} / 100 \mathrm{~mL}$ of high quality protein, providing a source for 9 EAA required for humans as well as organic nitrogen for growth and development (Schlimme and Meisel, 1995; Fox, 2003; Séverin and Wenshui, 2005). Bovine milk protein is comprised of mainly caseins $\left(\alpha_{\mathrm{S} 1}, \alpha_{\mathrm{S} 2}, \beta, \kappa\right.$, and $\left.\gamma\right)$, which constitute $\sim 80 \%$ of the proteins, and whey proteins ( $\alpha-\mathrm{LA}$, $\beta-\mathrm{LG}$, lactoferrin, immunoglobulins, serum albumin, glycomacropeptides, enzymes, and growth factors) accounting for the remaining 20\% (Linn, 1988; Fox, 2003; Heck et al., 2009). These proteins are the main source of bioactive peptides in milk and dairy products, which can be liberated by proteases during digestion, by proteases present in milk or during processing, following the addition of starter cultures, purified enzymes, or both (Korhonen and Pihlanto, 2006; Vargas-BelloPérez et al., 2019). These bioactive fragments have been shown to possess various beneficial functions, including antihypertensive, antimicrobial, immune-modulating, antithrombotic, and antioxidant properties (Kitts and Weiler, 2003; Haque and Chand, 2008; Vargas-BelloPérez et al., 2019).

\section{Milk Micronutrients}

Milk also contains various micronutrients such as vitamins and minerals which constitute vital compounds, particularly for neonatal development but also for healthy function and growth throughout life (Aleixo and Nóbrega, 2003). As mentioned earlier, the fat fraction of dairy compounds contributes significantly to vitamin and antioxidant content, including $\beta$-carotene, retinol, and tocopherol (de la Torre et al., 2018). Milk also contains various water-soluble vitamins, including $\mathrm{B}_{1}, \mathrm{~B}_{2}, \mathrm{~B}_{3}, \mathrm{~B}_{5}, \mathrm{~B}_{6}$, biotin, $\mathrm{B}_{12}$, folic acid, and vitamin $\mathrm{C}$ (Mehta, 2015). In addition, milk is well known particularly for its Ca content. Calcium is typically associated with bone and tooth health, but also contributes to nerve conduction, and muscle and vascular contraction (Beto, 2015). Minerals in milk exist in equilibrium between soluble and colloidal (considered insoluble) fractions; for example, $\mathrm{Ca}$ and $\mathrm{P}$ exist both in the soluble phase and attached to casein, and therefore their concentration correlates positively with that of protein.
Casein micelles are not only a nutritious source of AA, but also allow, through their colloidal structure, the transport of large amounts of $\mathrm{Ca}$ and $\mathrm{P}$ in stable form (Gaucheron, 2005).

\section{GRASS-FED PRODUCTS}

The primary findings of existing research studies on the compositional, nutritional, sensory, and functional properties of pasture-derived dairy products are summarized in Table 1, following a detailed description based on product type. It is important to note that some feeding studies relied on multiparous dairy cows, whereas others included a specific breed; certain studies focused on a particular stage of lactation, whereas others examined the effect of diet throughout the entire lactation period. As mentioned earlier, a variety of factors, including breed and stage of lactation, can affect the composition of milk and need to be taken into account when drawing conclusions across a variety of studies.

\section{Grass-Fed Milk}

In general, TMR feeding systems result in significantly higher milk yields from cows compared with that of pasture systems due to higher concentrate feeding. Pasture feeding has been demonstrated to increase fat and protein contents of milks (O'Callaghan et al., 2016b; de la Torre et al., 2018; Gulati et al., 2018), noting that the increase in protein and casein can modify the processing properties of milk, in particular rennet-induced gelation (O'Brien et al., 1999a; Amenu et al., 2006). In addition, it was previously shown that increasing protein and fat concentrations in milk results in a higher cheese yield (Fenelon and Guinee, 1999). Milk's protein and fat content are important not only from an industrial techno-functional perspective, but also for farmers in terms of milk price (Rice et al., 2019). A recent study linked pasture-based systems with profitability, taking into account different parameters including protein and fat contents in milk (Hanrahan et al., 2018).

Pasture-based diets not only affect fat concentration of milk, but also alter the fatty acid composition, in general toward a more nutritionally beneficial profile. As discussed by Palmquist (2006), fatty acids in the feed of cows have a significant effect on the composition of subsequent milk and dairy product fat. In particular, higher levels of ALA in milk from pasture compared with non-pasture-fed cows have been attributed to high content and rumen escape of ALA from forages. A decrease in SFA and in the ratio of n-6:n-3 was observed in grass-based milk by numerous researchers, compared 
Moscovici Joubran et al.: INVITED REVIEW: 2020 PERSPECTIVE ON PASTURE-BASED DAIRY SYSTEMS

7369

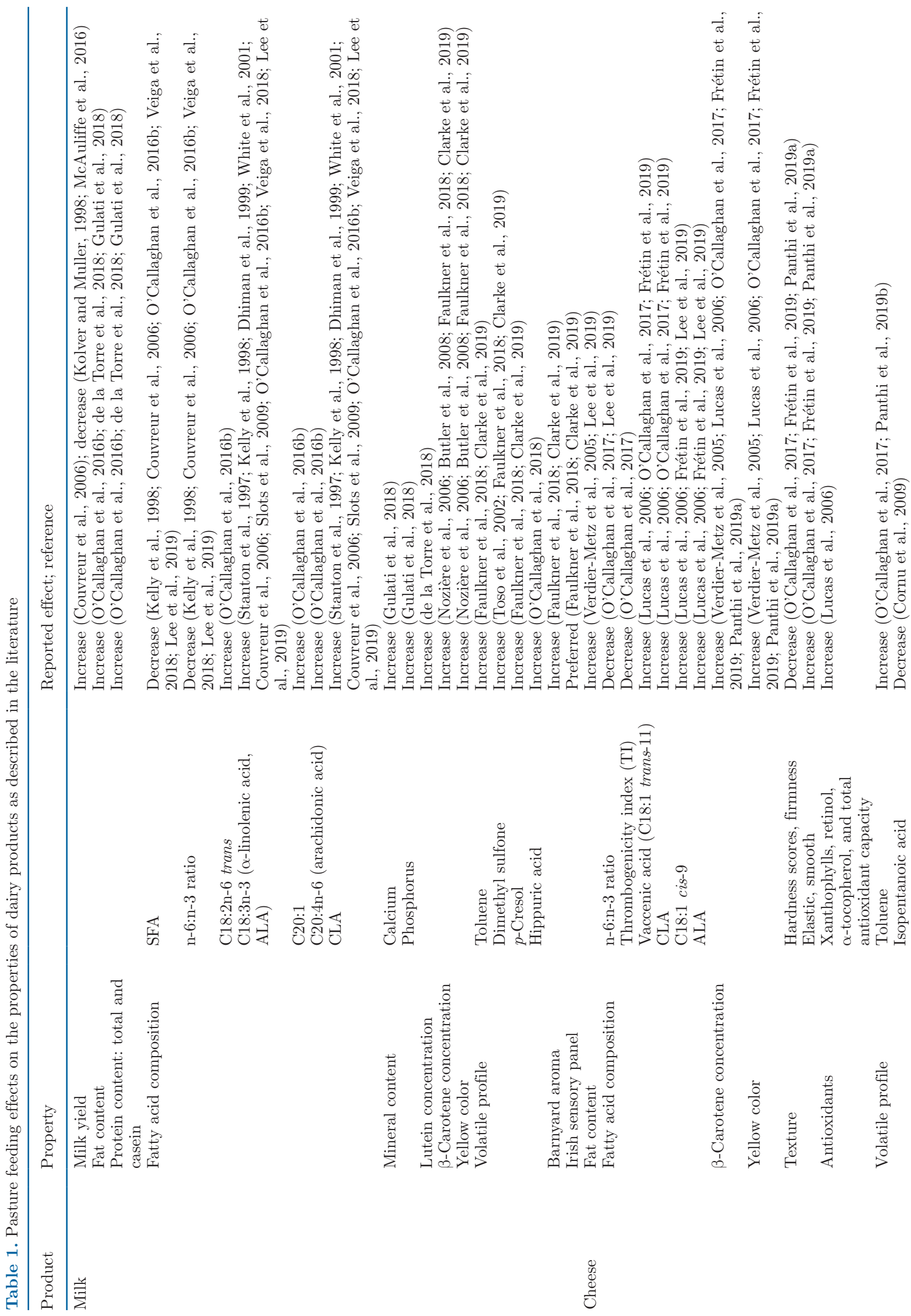




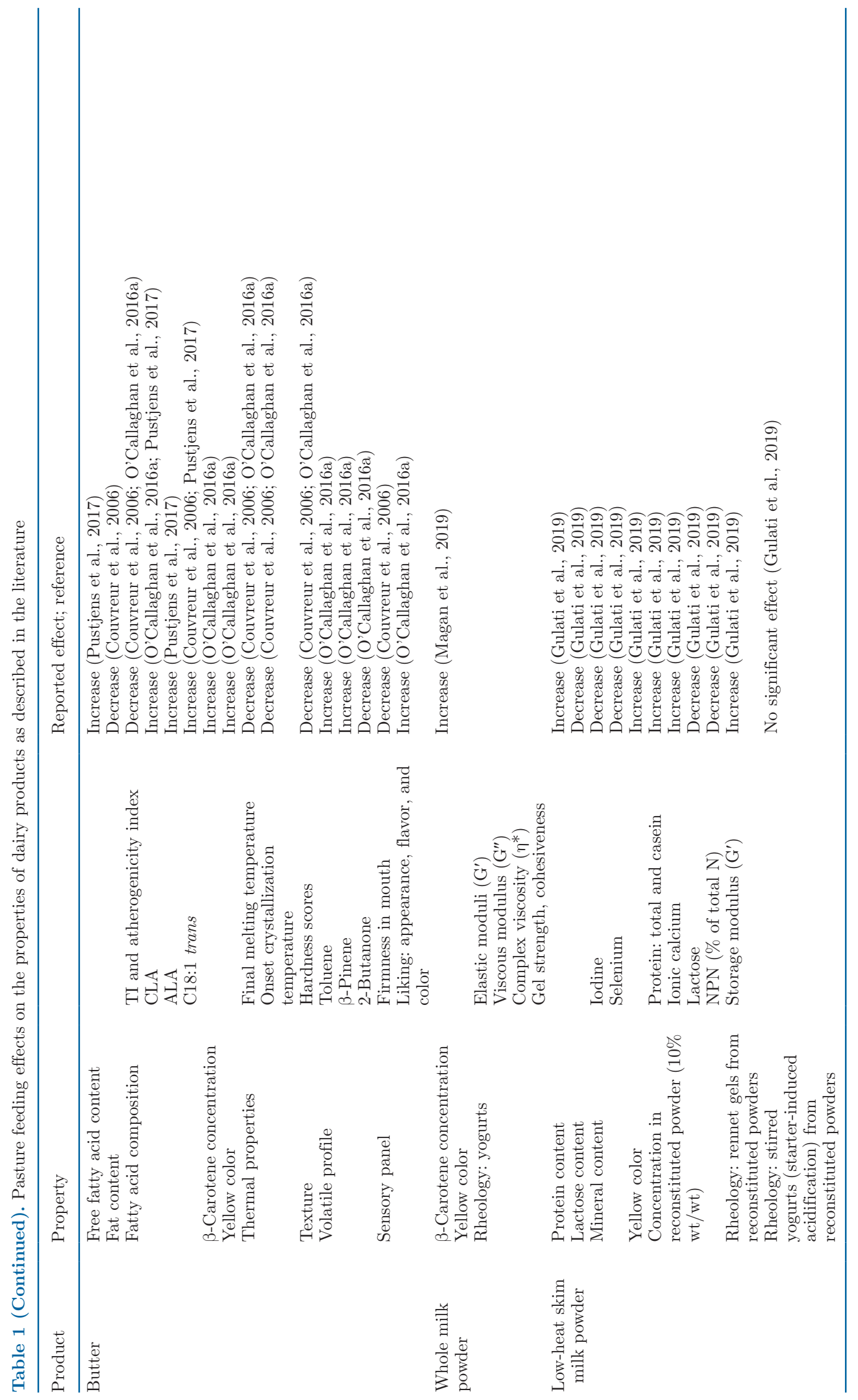


with TMR (Kelly et al., 1998; Couvreur et al., 2006; O'Callaghan et al., 2016b; Veiga et al., 2018; Lee et al., 2019). O'Callaghan et al. (2016b) reported significantly higher concentrations of $\mathrm{C} 18: 2 \mathrm{n}-6$ trans, C18: 3n-3 (ALA), C20:1, and C20:4n-6 (arachidonic acid) with a greater than 2-fold increase in the biologically active isomer of CLA, C18:2 cis-9,trans-11, in pasture feeding systems compared with TMR. Others have also demonstrated pasture intake resulted in milk richer in ALA and CLA (Stanton et al., 1997; Kelly et al., 1998; Dhiman et al., 1999; White et al., 2001; Couvreur et al., 2006; Slots et al., 2009; Veiga et al., 2018; Lee et al., 2019). Furthermore, O'Callaghan et al. (2016b) demonstrated that the fatty acid profile of milks from pasturebased and TMR feeding systems are distinctly different and that fatty acid profiling coupled with multivariate analysis could be harnessed for the verification of dairy products from pasture-based feeding systems. In addition to possible nutritional benefits, the modified fatty acid composition obtained from pasture-based milk can lead to modified processing properties such as changes in melting temperature and texture of various dairy products (Couvreur et al., 2006).

Furthermore its important to note that some of the major nutritional benefits typically associated with organic dairy products could in fact be linked to pasture feeding as opposed to the organic criteria alone. For example, the fatty acid profile of milk samples collected from US cows fed a nearly $100 \%$ forage-based diet was quantified and compared with a study of milk from cows under conventional and organic management. The pasture-based milk was found to be significantly different from both conventional and organic milk, containing a lower ratio of n-6:n-3 as well as higher levels of total n-3 and total CLA (Benbrook et al., 2018). In Denmark, pasture access is part of the requirements for organic dairy cows, who must be on pasture for at least $150 \mathrm{~d}$ a year between April 15 to November 1 (Slots et al., 2009). Nevertheless, a study comparing milk from different farms in Denmark (conventional or organic) and the United Kingdom (grazing, relying on pasture as almost the sole feed with $95 \pm 4 \% \mathrm{DMI}$ ) found clear differences between the UK and Danish organic milk. The UK grass-based milk had higher concentrations of CLA, trans-11-vaccenic acid, MUFA, and antioxidants, namely $\alpha$-tocopherol and $\beta$-carotene, than organic and conventional milks from Denmark (Slots et al., 2009).

Calcium and phosphorus are important elements in milk from both a nutritional and functional perspective, occurring in equilibrium between soluble and colloidal states (Tsioulpas et al., 2007; Fox et al., 2015). Calcium phosphate, playing a major role in tooth and bone health, is associated with the casein micelle and contributes toward its structural integrity (Gulati et al., 2018; Alothman et al., 2019). Gulati et al. (2018) demonstrated that milk from cows on pasture had a higher content of calcium and phosphorus. This can have implications for the dairy industry, affecting milk's heat stability, sedimentation, cheese-making properties, and so on (Tsioulpas et al., 2007; de Kruif et al., 2012; Alothman et al., 2019).

Grass-based milk was also found to contain higher amounts of lutein, a xanthophyll which is considered a fat-soluble antioxidant (de la Torre et al., 2018). Other studies have reported higher concentrations of $\beta$-carotene in milk from cows offered grass, which was also linked to the distinctly yellower, creamier color of grass-based milk (Nozière et al., 2006; Butler et al., 2008; Faulkner et al., 2018; Clarke et al., 2019). Moreover, studies observed higher concentrations of toluene, arising from $\beta$-carotene degradation, in grassderived milk samples (Faulkner et al., 2018; Clarke et al., 2019). Differences were obtained between feeding systems in terms of the product volatile profile. Dimethyl sulfone was identified in the pasture-derived samples, and highlighted as a potential volatile biomarker (Toso et al., 2002; Faulkner et al., 2018; Clarke et al., 2019), which was also identified in ruminal fluids of cows fed a pasture-based diet compared with TMR (O'Callaghan et al., 2018). Another potential volatile biomarker previously identified was $p$-cresol, which was higher in pasture-derived milk and associated with a barnyard aroma/flavor, whereas the TMR milk scored higher for hay-like flavor (Faulkner et al., 2018; Clarke et al., 2019). $p$-Cresol could be derived from $\beta$-carotene and isoflavones through microbiome metabolism in the rumen, which is supported by its presence in the ruminal fluid of grass-fed cows (Faulkner et al., 2018; O'Callaghan et al., 2018; Clarke et al., 2019). Hippuric acid was also highlighted by another study as a potential volatile marker for milk originating in pasture feeding systems (O'Callaghan et al., 2018). Using sensory profiling of products, an Irish sensory panel preferred the pasture-based milk when compared with TMR milk (Faulkner et al., 2018; Clarke et al., 2019). Such a result is perhaps unsurprising given that pasture-derived dairy products are the prevailing form in Ireland. Cheng et al. (2020) carried out a cross-cultural sensory analysis of skim milk powder (SMP) from pasture and nonpasture diets in Ireland, the United States, and China. The authors reported that differences in the sensory perception of SMP existed between US, Chinese, and Irish consumers. While Irish and US panelist preferences were aligned with their familiarity, the Chinese consumers were less discerning in relation to the cow diet. 


\section{Grass-Fed Cheese}

Different studies have evaluated the effect of pasture feeding on the properties of various cheeses. While numerous processing parameters such as starter culture choice are known to affect cheese characteristics to a large extent (Coulon et al., 2004), most results and trends reported were in agreement across the cheeses examined. In this context, Verdier-Metz et al. (2005) hypothesized that milk characteristics influenced by diet had a greater effect on cheese final characteristics such as color and sensory attributes in Cantal cheese, whereby the ripening process occurs mainly inside the curd since the curd/rind ratio is higher than in SaintNectaire cheese.

Pasture feeding was found to increase fat content in Cantal, Saint-Nectaire (Verdier-Metz et al., 2005), and Montasio type cheeses (Lee et al., 2019). Similar to findings about the fatty acid composition in pasturederived milk, an effect on cheese fatty acid composition was also observed in several studies. Significantly higher concentrations of vaccenic acid and CLA were obtained in pasture-based cheeses (Lucas et al., 2006; O'Callaghan et al., 2017; Frétin et al., 2019). Others have also observed a significant increase in C18:1 cis-9 and ALA (Lucas et al., 2006; Frétin et al., 2019; Lee et al., 2019). These modifications in fatty acid composition resulted in a more nutritionally beneficial fat composition in cheeses originating from pasture-based feeding systems, for example lower n-6:n-3 ratio and thrombogenicity index scores and reduced palmitic acid (C16:0) (O'Callaghan et al., 2017; Lee et al., 2019). Moreover, the different fatty acid composition altered cheese texture as a direct effect of the balance between SFA and UFA with low and high melting points. This resulted in lower hardness scores, and less firm, more elastic, smoother, and creamier texture of pasturederived cheeses (O'Callaghan et al., 2017; Frétin et al., 2019; Panthi et al., 2019a).

Similarly to milk originating from pasture-based systems, pasture-derived cheese was more yellow in color compared with TMR samples due to a higher levels of $\beta$-carotene content (Verdier-Metz et al., 2005; Lucas et al., 2006; O'Callaghan et al., 2017; Frétin et al., 2019; Panthi et al., 2019a). Moreover, when cows were fed a pasture diet, subsequent cheese was found to be richer in antioxidants such as xanthophylls, retinol, $\alpha$-tocopherol, as well as total antioxidant capacity (Lucas et al., 2006). In terms of the volatile profile, several studies reported an increase in toluene, similarly to milk samples (O'Callaghan et al., 2017; Panthi et al., 2019b). Cornu et al. (2009) highlighted a decrease in the odor of isopentanoic acid in Cantal cheese produced from pasture-based milk.

\section{Grass-Fed Butter}

Increasing the proportion of fresh grass in the diet has been demonstrated to result in lower solid fat content (Couvreur et al., 2006). Pasture-based feeding has been demonstrated to modify the fatty acid composition of butter, including a significant increase in the concentrations of CLA (O'Callaghan et al., 2016a; Pustjens et al., 2017), ALA (Pustjens et al., 2017), and C18:1 trans (Couvreur et al., 2006; Pustjens et al., 2017). Consequently, pasture-derived butter had lower thrombogenicity index and atherogenicity index scores (Couvreur et al., 2006; O'Callaghan et al., 2016a). Changes in the fatty acid composition, particularly the spreadability index (C16:0/C18:1), led to significant differences in thermal and textural properties, including a decrease in final melting temperatures and the onset of crystallization occurring at lower temperatures, resulting in lower hardness scores for pasture-derived butter (Couvreur et al., 2006; O'Callaghan et al., 2016a). In accordance with results obtained for pasture-based milk and cheese, butter originating from a pasture-based feeding system was yellower in color and richer in $\beta$-carotene (O'Callaghan et al., 2016a). Volatile profiling of butters indicated higher concentrations of toluene and $\beta$-pinene as well as a lower concentration of 2-butanone in grass-based butters compared with TMR samples (O'Callaghan et al., 2016a). Increasing the proportion of fresh grass in the cows' diet resulted in lower firmness in the mouth during sensory evaluation (Couvreur et al., 2006), whereas Irish assessors gave higher scores to pasturederived butters for liking of appearance, flavor, and color (O'Callaghan et al., 2016a). Garvey et al. (2020) interestingly examined the cross-cultural preferences for salted butters from pasture and non-pasture-based feeding systems in Ireland, the United States, and Germany. The authors reported that sensory attribute differences based on cow diet were evident across the 3 countries, which are likely influenced by familiarity and concluded that different feeding systems affect crosscultural perception of butter.

\section{Other Grass-Fed Dairy Products}

Magan et al. (2019) compared the effect of pasture feeding system versus TMR on compositional and functional characteristics of whole milk powders (WMP). The authors reported that pasture-derived powder was significantly more yellow in color than TMR due to increased $\beta$-carotene content in pasture-derived samples, in line with aforementioned studies demonstrating this effect in pasture-based milk, cheese, and butter. Furthermore, yogurts produced from pasture-derived WMP had higher elastic moduli $\left(\mathbf{G}^{\prime}\right)$, viscous modulus $\left(\mathbf{G}^{\prime \prime}\right)$, 
and complex viscosity $\left(\boldsymbol{\eta}^{*}\right)$ than TMR samples, which characterize a stronger gel. Pasture-based yogurts also resulted in a more cohesive gel. Such results indicate there can be technological considerations between milk source and final product properties.

Another study looked at low-heat SMP produced in mid and late lactation from milk derived from grazing cows or cows housed indoors offered TMR (Gulati et al., 2019). Again, a yellower color was obtained for pasturederived samples. In addition, pasture-derived low-heat SMP contained a higher protein content, and lower lactose, iodine, and selenium content compared with the corresponding TMR powder. Reconstituted powder (at 10\% wt/wt) originating from milk from pasturebased cows had higher levels of protein, casein, and ionic calcium, and lower concentrations of lactose and NPN (\% of total N). Moreover, pasture feeding resulted in rennet gels with a higher storage modulus $\left(G^{\prime}\right)$ than the TMR sample. Nevertheless, there was no significant effect on the properties of stirred yogurt produced from the reconstituted powder, based on starter-induced acidification. This highlighted that the application and processing conditions of the reconstituted powder also play a role in its functionality (Gulati et al., 2019).

Various compositional, sensory, techno-functional, and nutritionally beneficial effects have previously been reported for grass-fed milk and other such dairy products (Table 1). These results suggest that nutritional benefits should be further supported with data from in vivo human trials, for example those comparing grass-fed with non-grass-fed dairy products, in addition to dose-response studies. Furthermore, studies to date have focused on milk, cheese, and butter with information lacking on other dairy products such as milk powders and yogurts. Finally, it is important to highlight that seasonality, cow breed, and genetics also play a major role in dairy product composition and properties (Knowles et al., 2006; Alothman et al., 2019) and these factors should be taken into account when designing experiments, particularly feeding trials.

\section{COW HEALTH, WELFARE, AND SUSTAINABILITY}

Consumers typically perceive grass-fed or pasturebased farming positively, in terms of cow welfare and environmental sustainability (Ellis et al., 2009; Heerwagen et al., 2013; Elgersma, 2015; Armbrecht et al., 2019; Shortall, 2019). The importance of these 2 topics, cow welfare and sustainability, is predicted to continue rising in consumer acceptance of foods and in particular of dairy products (Britt et al., 2018). Therefore, aspects of pasture-based dairy systems could be harnessed and utilized for marketing purposes on the grounds of cows having freedom to roam in more sustainable systems (Shortall, 2019).

\section{Animal Health and Welfare}

Animal welfare is defined not only as maintaining animals' health, but also enabling animals to display natural behavior, such as mobility, lying down, and standing up motions and resting without restrictions (Dawkins, 2004; Armbrecht et al., 2019). Vasseur (2017) classified the indicators utilized in animal welfare assessments into risk factors, either housing based (density, stall size) or management based (access to pasture); and outcome measures of welfare, which are essentially the results of how housing and management affect the animal's welfare status. A European Food Safety Authority report on the effects of different farming systems in the European Union on dairy cow welfare and disease emphasized the benefits of exposure to pasture, giving countries that practice pasture-based systems a clear welfare advantage over others (European Food Safety Authority, 2009). Grazing outdoors in groups has been shown to provide cows opportunities to further express normal behavior, including social contact and herd hierarchy taking place (Legrand et al., 2009). Grazing also reduces prevalence of health issues such as mastitis, integument alterations, and mortality (Washburn et al., 2002; Hernandez-Mendo et al., 2007; Olmos et al., 2009a,b; Burow et al., 2012). On the other hand, housing cows indoors in confined facilities has been shown to restrict natural behavior and contribute to the prevalence of diseases including mastitis, lower reproductive welfare, and lameness (Britt et al., 1986; Dobson and Smith, 2000; von Borell et al., 2007; Armbrecht et al., 2019). Lameness in particular is generally considered a good measurement of welfare, as it can result from management factors (zero grazing, uncomfortable stalls, walking or standing on damaged surfaces, or more slurry), or from infectious disease or lesions (von Keyserlingk et al., 2009). In a recent study, incidence of lameness and dairy cow locomotion scores in pasture-based systems are shown to be lower than previously reported information from indoor systems (O'Connor et al., 2020). In addition, when cows are housed indoors in group housing, research has shown that this is more positive than individual housing in terms of social skills and some cognitive deficits (Costa et al., 2016).

Nevertheless, there are numerous challenges to correctly assess cow welfare in a holistic way and in real time; therefore, information is still lacking that assesses the effect of pasture feeding on cows' health and wellbeing (Armbrecht et al., 2019). Recently, a study evalu- 
ated cow welfare in German dairy farms combining the Welfare Quality Protocol for dairy cattle and routine data recordings. Pasture-based herds scored higher for comfort around resting, whereas the group housed indoors without any pasture access received poorer scores for lameness, lesions, and absence of injuries and hairless patches (Armbrecht et al., 2019). Another recent study linked cow mobility score and other parameters such as BCS, claw disorders (both type and severity), and cow parity, highlighting the need to routinely monitor cows even with slight deviations from optimal mobility pattern to avoid further deterioration (O'Connor et al., 2019).

Previous concern has been expressed that farm expansion (Kelly et al., 2020) may risk animal welfare and health as farm sizes and herds increase (Britt et al., 2018; Shortall, 2019; Kelly et al., 2020). Moreover, intensification can be associated with genetic selection for higher milk yield, which has been identified as a major factor causing poor welfare and health problems, which have been correlated with the incidence of lameness, mastitis, fertility, and metabolic disorders (Miglior et al., 2017). However, Beggs et al. (2019), on examination of pasture-based dairy farms of varying sizes in Australia, did not find strong relationships between herd size and a series of animal welfare outcomes. Their study concluded that there was considerable variation in both risks to animal welfare and use of mitigating strategies across farms of all sizes. A study by O'Connor et al. (2020) showed that cows that had a higher economic breeding index had a lower locomotion score and reduced lameness issues.

\section{Sustainability}

Substantial challenges lie ahead for agriculture in the coming decades. Agriculture globally must produce more food for a growing, increasingly affluent population, while competing for access for increasingly scarce natural resources, preserving biodiversity and water quality, mitigating the effects of climate change, adapting to new plant and animal disease threats and addressing consumer concerns around issues such as animal welfare, while reducing feed:food competition.

In the United States the legal definition for sustainable agriculture is "an integrated system of plant and animal production practices having a site-specific application that will, over the long-term; (A) satisfy human food and fiber needs; (B) enhance environmental quality and the natural resource base upon which the agricultural economy depends; (C) make the most efficient use of nonrenewable resources and on-farm resources and integrate, where appropriate, natural biological cycles and controls; (D) sustain the economic vi- ability of farm operations; and (E) enhance the quality of life for farmers and society as a whole" (USC Title $7,2011)$. In general, globally, modern day farming has been associated with major sustainability challenges (Arvidsson Segerkvist et al., 2020); however, the industry is striving to provide affordable and nutritious food items, cognizant of the need to optimize use of natural resources use and reduce environmental impacts (Miller and Auestad, 2013).

Dairy farm expansion may have an effect on greenhouse gas and ammonia emissions as well as water quality (Ledgard et al., 1998; Clark et al., 2007; Wales and Kolver, 2017b; Shortall, 2019; Kelly et al., 2020). There is a predicted strong link between the profitability of dairy farms and their sustainability (Britt et al., 2018); thus, farmers have an incentive to improve the sustainability of their farms. In particular, pasture-based systems were shown to consume less energy compared with indoor systems (O'Brien and Hennessy, 2017). Moreover, numerous studies have demonstrated how pasture feeding systems are environmentally sustainable. One study demonstrated that Irish milk emits the lowest greenhouse gas footprint in the European Union per unit of fat- and protein-corrected milk (Leip et al., 2010). A comparative life cycle assessment between pasture-based and confinement dairy farms considered environmental impacts such as global warming, eutrophication, acidification, land use, and nonrenewable energy, in terms of on-farm, off-farm, and combined environmental impacts (O'Brien et al., 2012; O'Brien and Hennessy, 2017). This study indicated that for the metric of milk production per farmland area, the environmental impact (in relation to potential resource utilization and pollutants) was lower for the pasture-based system than the confinement system. Furthermore, the pasture-based system had a lower total environmental impact compared with the confinement system.

Murphy et al. (2017) demonstrated that the water footprint of milk, evaluated on 24 Irish dairy farms, was mainly comprised of growing grass with green water (i.e., the consumption of soil moisture due to evapotranspiration). Knowledge of water use on its own has less utility than knowledge of water use relative to water availability/scarcity known as a water stress index. The stress-weighted water footprint method used by Pfister et al. (2009) provides a characterization factor for assessing the effects of water consumption at river basin or watershed level. Based on this method, the stressed weighted effect of the production of $1 \mathrm{~kg}$ of fatand protein-corrected milk in Ireland was calculated to be $0.4 \mathrm{~L} \mathrm{H}_{2} \mathrm{O}$-equivalents (Murphy et al., 2017).

An Irish study on water quality showed that in spite of a $20 \%$ increase in stocking rate, there was a decline of nitrogen concentration in Irish groundwater over 11 
yr (Huebsch et al., 2013). The authors established that to improve groundwater quality, steps such as improved grazing management, increased usage of organic manures, and methods for reduced cultivation reseeding should be taken. Ultimately, significant strides could be made to reduce nitrogen loss pathways through reducing the nitrogen surplus and increasing the efficiency of the systems evaluated.

Advanced technologies and sensors could potentially help improve emissions, water quality, soil, and crop health (Britt et al., 2018). For example, near-infrared sensors could determine mass and nutrient density of swards by measuring canopy spectral reflectance or using a variety of sensor types that will facilitate a better classification of cow's ingestive behaviors (i.e., eating time and rate, bite size, and number of chews; Wales and Kolver, 2017b). The incorporation of diverse pastures requires further studies to optimize their use and clearly demonstrate they do not adversely affect milk solids yield, animal nutrition and health, or both (Wales and Kolver, 2017b). Concentrate supplementation can also increase $\mathrm{N}$ partitioning into milk in a pasture feeding system, as recently shown for late lactating cows (McKay et al., 2019). Another promising approach to reduce $\mathrm{N}$ loss, which targets the gaseous emissions of nitrous oxide and ammonia by slowing urea hydrolysis, is to use fertilizers containing urease inhibitors, such as $N$-(n-butyl) thiophosphoric triamide (de Klein and Eckard, 2008; Harty et al., 2016).

\section{THE NEED FOR NATIONALLY ACCREDITED GRASS-FED STANDARDS}

It is essential that a clear and well-regulated standard is developed for grass-fed dairy products. Consumers, who see various benefits in these products and may be willing to pay more for them (Shalloo et al., 2018), should have confidence that products advertised as grass-fed are indeed correctly labeled as such. This is becoming more important as more evidence supports compositional, functional, nutritional, and sustainability advantages for grass-fed produce, as detailed earlier. Currently, this term is widely used on labels and company websites, with consumer confusion arising from numerous definitions and criteria of grass-fed in different countries and even by various companies in the same country. It is clear that there are numerous production methods for dairy practiced throughout the world for a variety of reasons including intensification to optimize milk yields, limited land and availability of natural resources or climatic conditions. As such the development of a universal grass-fed standard would be difficult but it should reflect the proportion of the diet that is grass based in the form of grazed grass or grass silage. This standard would equip the consumer with the information needed to make an informed decision.

\section{Quantifying Pasture Levels}

A key aspect that should be included within a grassfed claim is the quantity of pasture used in the diet of dairy cows, which could also offer an indication of how long cows spend outside grazing (Shalloo et al., 2018). This will help guarantee a minimum requirement for pasture-based products but can also help differentiate different levels of "grass-fed" and may facilitate an internationally recognized standard. In some countries in Europe, cows may spend only a few hours on grass a day and the product will be labeled as pasture based (Shortall, 2019). Currently, some milk suppliers may receive premium payments if they allow their cows to graze for a minimum period (Elgersma, 2015). In New Zealand, Fonterra uses a "Certified Grass Fed" claim, which is certified by AsureQuality, an independent conformity assessment body. The company states on their website that their cows "consume on average 85 percent of their diet as grass." Furthermore, cows spend at least $90 \%$ of their time outside grazing as a minimum requirement of the standard (Fonterra, 2020). Synlait, another New Zealand dairy company, offers farmers an extra premium price, on top of the company's base price for "grass-fed milk," if cows are exclusively fed pasture without imported feeds (Synlait, 2015).

Some US companies claim to be $100 \%$ grass fed, for example, a new Certified Grass-Fed Organic Livestock Program and Certification Mark, launched by Maple Hill and Organic Valley and launched in February 2019, called "grass-fed organic product." Under the program, dairy cows must be exclusively fed a grass diet and given a sizable area of pasture for grazing with at least $60 \%$ of the cow's food originating from pasture over a 150-d grazing season to qualify. The farms must already be USDA-certified organic, and once the milk leaves the farm, it has to stay segregated from conventional milk and organic milk to ensure integrity from farm to table. Cows have full access to pasture, $365 \mathrm{~d}$ a year (weather permitting). They eat only grass, except for hay and silage as a supplement when no grass is available.

Ireland's outdoor grass-based dairy production has been clearly presented as a differentiator for Irish dairy by Bord Bia or individual dairy companies. Furthermore, the development of verifiable proof points is called for in the Bord Bia Statement of Strategy 2019-2021 (Bord Bia, 2019) to assist in making verified claims around grass-fed dairy with robust data to support it. Overall, Shalloo et al. (2018) categorized the current claims internationally about the level of grass in the diet into 3 groups: $100 \%$ grass fed, a specific 
percentage of grass stated, or a general "grass-fed" label without any further information. O'Brien et al. (2018) developed a methodology to quantify pasture levels in the diet of Irish dairy cows. This model quantifies the levels of grazed grass and grass silage in dairy cow diet on a monthly basis using milk production and livestock numbers, turnout and housing information, concentrate feeding information, and can be populated with data from the National Farm Survey or the Sustainable Dairy Assurance Scheme. Nevertheless, information in these databases is collected retrospectively; therefore, the current claims by Irish companies are accumulated over several years on a rolling average basis. Another widely used database is PastureBase Ireland for commercial grassland farms operating since 2013, which contains more up to date information compared with National Farm Survey or Sustainable Dairy Assurance Scheme. Since farmers enter data in kilograms of grass $\mathrm{DM}$ per hectare or in centimeters, in real time, it is possible to evaluate the performance of individual paddocks both within and across years (Hanrahan et al., 2018) and also to determine the diets of dairy cows on a live basis. In 2018, there were over 6,000 dairy farmers (out of 18,000 in Ireland) on the PastureBase Ireland system and nearly 1,400 farms that completed weekly farm covers. Shalloo et al. (2018, page 5) highlighted that a grass-fed standard "should be developed to an internationally recognized standard (ISO)." As such, one of the important aspects in a standard should be an independent and centralized body in each country collecting and overseeing the data used for the claim of grass-fed, which would then be overseen by an international regulatory body. An Irish grass-fed standard has been established accredited by the Irish National Accreditation Board and sets out the criteria that must be adhered to for milk from individual farms, and for milk pooled for primary processing, to be classified as "grass-fed" (Bord Bia, 2020). Using the Grass-Fed quantification model developed in Teagasc and integrated web-based software (Grass-Fed Dairy Model; O'Brien et al., 2018), the numerical value of the "grass-fed figure" for individual farms assessed is assessed on a three year rolling average grass-fed figure for that farm; "the average Grass-Fed figure for a group of herds that constitute a pool of milk for primary or secondary processing must achieve a weighted average of $95 \%$ on a fresh weight basis," while "the minimum acceptable grass-fed figure for an individual herd to qualify as Grass-Fed is $90 \%$ on a fresh weight basis" (Bord Bia, 2020). Cows must graze on pasture at least $160 \mathrm{~d}$ (national average days at grass - i.e., $240 \mathrm{~d}$ - less $80 \mathrm{~d}$ ), and "for every product batch dispatched a corresponding 'Grazing Days Report' will be generated and will be accessible online to the processor" (Bord Bia, 2020, page 11).

\section{Authentication of Grass-Fed Dairy}

One of the key hurdles is to accurately verify and authenticate grass-fed dairy products as such. Following a standard clearly defining what can be considered as grass fed and placing a regulatory system in place to verify the conditions are met, the next step is to be able to authenticate products from around the world. Methods to do so can help further support and back up a paper trail classifying a product as grass fed and, with the lack of an international grass-fed standard, enable the authentication of international products labeled grass fed, as such. Nevertheless, research in this area is still preliminary and requires more data. Numerous studies have shown pasture-based dairy products could be differentiated from products originating in cows fed TMR by fatty acid profiling, even throughout the entire lactation (Capuano et al., 2014; Coppa et al., 2015; O'Callaghan et al., 2016b). Therefore, it was suggested fatty acid profiling could be used as a verification tool for grass-derived products over TMR (O'Callaghan et al., 2016b). More recently, fatty acid profiling was shown to successfully distinguish even organic from pasture-based milk from the Netherlands (Liu et al., 2020). In addition, pasture-derived versus cereal-derived milk and cheese samples were shown to be successfully differentiated by their terpenes and carotenoids (Tornambé et al., 2006; Slots et al., 2009). Previous studies have indicated the possibility to harness volatile profiling for authentication purposes, with $p$-cresol, a degradation product of $\beta$-carotene, specifically highlighted as a potential marker in milk, which is also linked to sensory attributes (Faulkner et al., 2018; Kilcawley et al., 2018; Clarke et al., 2019).

Advanced analytical methods such as quantitative nuclear magnetic resonance $\left({ }^{1} \mathrm{H}-\mathrm{NMR}\right)$ were also shown to discriminate pasture fed from TMR products (O'Callaghan et al., 2018; Boiani et al., 2019; Panthi et al., 2019b). Quantitative nuclear magnetic resonancebased metabolomics has numerous advantages; it is a nondestructive method with a detection capacity of all mobile hydrogen-containing molecules, and hence is considered a promising technique for the verification of grass-based products (Sundekilde et al., 2013). Recently, O'Sullivan et al. (2021) have highlighted the potential for milk stable isotope profile to be used to authenticate milk source. Another possibly promising nondestructive and relatively cheap technique is near-infrared spectroscopy, which was demonstrated to distinguish no-pasture from pasture milk, even with 
only $30 \%$ of pasture in the diet (Coppa et al., 2012; Valenti et al., 2013). Near-infrared spectroscopy was also shown to have the capacity to classify cheese samples (Abondance, Tomme de Savoie, and Cantal) from pasture versus preserved forage (Andueza et al., 2013). Moreover, it was previously used to predict carotenoid content and fatty acid profiles in dairy products (Lucas et al., 2008a,b; Coppa et al., 2010). Fourier-transform infrared spectroscopy analysis of milk samples was also suggested as a potential authentication method after it successfully discriminated milk from cows that had fresh grass in the daily ration and those that did not, as well as authenticated pasture grazing (Capuano et al., 2014). To this end, the challenge is to be able to correctly authenticate a wide range of pasture-based dairy products using simple, high-throughput, and lowcost screening techniques (Bergamaschi et al., 2020). This will enable future verification that dairy products are indeed pasture-based and possess all the benefits associated with it.

\section{CONCLUSIONS AND OUTLOOK}

This review has demonstrated the significant potential pasture-based fresh grass feeding systems have for the future of milk and dairy products from different aspects. These include compositional and nutritional properties as summarized for the various dairy products, but also other considerable features that are gaining increasing attention including sensory attributes, animal health and welfare, and sustainability. However, some gaps still exist that should be addressed in future research, including human trials examining the health benefits of consuming pasture versus non-pasture-based products, in light of the myriad of advantages and benefits pasture-based products offer. There is a need for robust methods to verify grass fed in the form of a verifiable claim. With that, there is scope for future research to develop rapid high-throughput analysis methods to classify and authenticate grass-fed products as developing a live system would allow milk to be assembled based on its grass-fed status throughout the year.

\section{ACKNOWLEDGMENTS}

This work is funded by Food for Health Ireland (FHI). The FHI-3 project is funded by Enterprise Ireland (Dublin, Ireland) and industry, and the grant number is TC/2018/0025. The authors have not stated any conflicts of interest.

\section{REFERENCES}

Aleixo, P. C., and J. A. Nóbrega. 2003. Direct determination of iron and selenium in bovine milk by graphite furnace atomic absorption spectrometry. Food Chem. 83:457-462. https://doi.org/10.1016/ S0308-8146(03)00224-3.

Alothman, M., S. A. Hogan, D. Hennessy, P. Dillon, K. N. Kilcawley, M. O'Donovan, J. Tobin, M. A. Fenelon, and T. F. O'Callaghan. 2019. The "grass-fed" milk story: Understanding the impact of pasture feeding on the composition and quality of bovine milk. Foods 8:350. https://doi.org/10.3390/foods8080350.

Amenu, B., T. Cowan, H. Deeth, and R. Moss. 2006. Impacts of feeding system and season on milk composition and Cheddar cheese yield in a subtropical environment. Aust. J. Exp. Agric. 46:299 306. https://doi.org/10.1071/EA04068.

Andueza, D., C. Agabriel, I. Constant, A. Lucas, and B. Martin. 2013. Using visible or near infrared spectroscopy (NIRS) on cheese to authenticate cow feeding regimes. Food Chem. 141:209-214. https: //doi.org/10.1016/j.foodchem.2013.02.086.

Armbrecht, L., C. Lambertz, D. Albers, and M. Gauly. 2019. Assessment of welfare indicators in dairy farms offering pasture at differing levels. Animal 13:2336-2347.

Arvidsson Segerkvist, K., H. Hansson, U. Sonesson, and S. Gunnarsson. 2020. Research on environmental, economic, and social sustainability in dairy farming: A systematic mapping of current literature. Sustainability 12:5502. https://doi.org/10.3390/ su12145502.

Auldist, M. J., and I. B. Hubble. 1998. Effects of mastitis on raw milk and dairy products. Aust. J. Dairy Technol. 53:28-36.

Auldist, M. J., L. C. Marett, J. S. Greenwood, M. Hannah, J. L. Jacobs, and W. J. Wales. 2013. Effects of different strategies for feeding supplements on milk production responses in cows grazing a restricted pasture allowance. J. Dairy Sci. 96:1218-1231. https:/ /doi.org/10.3168/jds.2012-6079.

Auldist, M. J., A. R. Napper, and E. S. Kolver. 2000a. Contribution of nutrition to seasonal variation of milk composition in New Zealand Friesian and US Holstein dairy cows. Asian-Australas. J. Anim. Sci. 13:513-516.

Auldist, M. J., N. A. Thomson, T. R. Mackle, J. P. Hill, and C. G. Prosser. 2000b. Effects of pasture allowance on the yield and composition of milk from cows of different $\beta$-lactoglobulin phenotypes. J. Dairy Sci. 83:2069-2074. https://doi.org/10.3168/jds .S0022-0302(00)75088-0.

Australian Bureau of Statistics. 2020. Agricultural Statistics. Accessed Apr. 7, 2021. https://www.abs.gov.au/agriculture.

Bargo, F., L. D. Muller, G. A. Varga, J. E. Delahoy, and T. W. Cassidy. 2002. Ruminal digestion and fermentation of high-producing dairy cows with three different feeding systems combining pasture and total mixed rations. J. Dairy Sci. 85:2964-2973. https://doi .org/10.3168/jds.S0022-0302(02)74382-8.

Beggs, D. S., E. C. Jongman, P. H. Hemsworth, and A. D. Fisher. 2019. The effects of herd size on the welfare of dairy cows in a pasture-based system using animal- and resource-based indicators. J. Dairy Sci. 102:3406-3420. https://doi.org/10.3168/jds.2018-14850.

Benbrook, C. M., G. Butler, M. A. Latif, C. Leifert, and D. R. Davis. 2013. Organic production enhances milk nutritional quality by shifting fatty acid composition: A United States-wide, 18-month study. PLoS One 8:e82429. https://doi.org/10.1371/journal.pone .0082429 .

Benbrook, C. M., D. R. Davis, B. J. Heins, M. A. Latif, C. Leifert, L. Peterman, G. Butler, O. Faergeman, S. Abel-Caines, and M. Baranski. 2018. Enhancing the fatty acid profile of milk through forage-based rations, with nutrition modeling of diet outcomes. Food Sci. Nutr. 6:681-700. https://doi.org/10.1002/fsn3.610.

Bergamaschi, M., C. Cipolat-Gotet, A. Cecchinato, S. Schiavon, and G. Bittante. 2020. Chemometric authentication of farming systems of origin of food (milk and ripened cheese) using infrared spectra, fatty acid profiles, flavor fingerprints, and sensory descriptions. Food Chem. 305:125480. https://doi.org/10.1016/j.foodchem.2019 .125480 . 
Beto, J. A. 2015. The role of calcium in human aging. Clin. Nutr. Res. 4:1-8. https://doi.org/10.7762/cnr.2015.4.1.1.

Boiani, M., U. Sundekilde, L. M. Bateman, D. G. McCarthy, A. R. Maguire, A. Gulati, T. P. Guinee, M. Fenelon, D. Hennessy, R. J. FitzGerald, and P. M. Kelly. 2019. Integration of high and low field $1 \mathrm{H}$ NMR to analyse the effects of bovine dietary regime on milk metabolomics and protein-bound moisture characterisation of the resulting mozzarella cheeses during ripening. Int. Dairy J. 91:155-164. https://doi.org/10.1016/j.idairyj.2018.08.016.

Bord Bia. 2019. 2019-2021 Statement of Strategy. Accessed Jan. 2021. https://www.bordbia.ie/about/about-bord-bia/statement -of-strategy/\#: : text=Statement \%20of\%20Strategy\%202019 \%2D2021,agri\%2Dfood\%20sector\%20to\%202025.

Bord Bia. 2020. Grass Fed Dairy Standard. Accessed Jan. 2021. https: //www.bordbia.ie/globalassets/bordbia2020/farmers--growers/ grass-fed-standard/grass-fed-dairy-rev01-final.pdf.

Britt, J. H., R. A. Cushman, C. D. Dechow, H. Dobson, P. Humblot, M. F. Hutjens, G. A. Jones, P. S. Ruegg, I. M. Sheldon, and J. S. Stevenson. 2018. Invited review: Learning from the future-A vision for dairy farms and cows in 2067. J. Dairy Sci. 101:3722-3741. https://doi.org/10.3168/jds.2017-14025.

Britt, J. H., R. G. Scott, J. D. Armstrong, and M. D. Whitacre. 1986. Determinants of estrous behavior in lactating Holstein cows. J. Dairy Sci. 69:2195-2202. https://doi.org/10.3168/jds.S0022 -0302(86)80653-1.

Broderick, G. A. 2017. Review: Optimizing ruminant conversion of feed protein to human food protein. Animal 12:1722-1734.

Burow, E., T. Rousing, P. T. Thomsen, N. D. Otten, and J. T. Sørensen. 2012. Effect of grazing on the cow welfare of dairy herds evaluated by a multidimensional welfare index. Animal 7:834-842.

Butler, G., J. H. Nielsen, T. Slots, C. Seal, M. D. Eyre, R. Sanderson, and C. Leifert. 2008. Fatty acid and fat-soluble antioxidant concentrations in milk from high- and low-input conventional and organic systems: Seasonal variation. J. Sci. Food Agric. 88:14311441. https://doi.org/10.1002/jsfa.3235.

Capuano, E., G. van der Veer, R. Boerrigter-Eenling, A. Elgersma, J. Rademaker, A. Sterian, and S. M. van Ruth. 2014. Verification of fresh grass feeding, pasture grazing and organic farming by cows farm milk fatty acid profile. Food Chem. 164:234-241. https://doi .org/10.1016/j.foodchem.2014.05.011.

Cheng, Z., M. G. O'Sullivan, J. P. Kerry, M. A. Drake, S. Miao, D. Kaibo, and K. N. Kilcawley. 2020. A cross-cultural sensory analysis of skim powdered milk produced from pasture and non-pasture diets. Food Res. Int. 138:109749. https://doi.org/10.1016/j.foodres .2020.109749.

Clark, D. A., J. R. Caradus, R. M. Monaghan, P. Sharp, and B. S. Thorrold. 2007. Issues and options for future dairy farming in New Zealand. N. Z. J. Agric. Res. 50:203-221. https://doi.org/10.1080/ 00288230709510291.

Clarke, H. J., C. Griffin, D. K. Rai, T. F. O'Callaghan, M. G. O'Sullivan, J. P. Kerry, and K. N. Kilcawley. 2019. Dietary compounds influencing the sensorial, volatile and phytochemical properties of bovine milk. Molecules 25:26. https://doi.org/10.3390/ molecules25010026.

Clarys, P., T. Deliens, I. Huybrechts, P. Deriemaeker, B. Vanaelst, W. De Keyzer, M. Hebbelinck, and P. Mullie. 2014. Comparison of nutritional quality of the vegan, vegetarian, semi-vegetarian, pescovegetarian and omnivorous diet. Nutrients 6:1318-1332. https:// doi.org/10.3390/nu6031318.

Coppa, M., C. Chassaing, A. Ferlay, C. Agabriel, C. Laurent, G. Borreani, R. Barcarolo, T. Baars, D. Kusche, O. M. Harstad, J. Verbič, J. Golecký, C. Delavaud, Y. Chilliard, and B. Martin. 2015. Potential of milk fatty acid composition to predict diet composition and authenticate feeding systems and altitude origin of European bulk milk. J. Dairy Sci. 98:1539-1551. https://doi.org/10 $.3168 /$ jds.2014-8794.

Coppa, M., A. Ferlay, C. Leroux, M. Jestin, Y. Chilliard, B. Martin, and D. Andueza. 2010. Prediction of milk fatty acid composition by near infrared reflectance spectroscopy. Int. Dairy J. 20:182-189. https://doi.org/10.1016/j.idairyj.2009.11.003.
Coppa, M., B. Martin, C. Agabriel, C. Chassaing, C. Sibra, I. Constant. B. Graulet, and D. Andueza. 2012. Authentication of cow feeding and geographic origin on milk using visible and near-infrared spectroscopy. J. Dairy Sci. 95:5544-5551. https://doi.org/10 $.3168 /$ jds.2011-5272.

Cornu, A., N. Rabiau, N. Kondjoyan, I. Verdier-Metz, P. Pradel, P. Tournayre, J. L. Berdagué, and B. Martin. 2009. Odour-active compound profiles in Cantal-type cheese: Effect of cow diet, milk pasteurization and cheese ripening. Int. Dairy J. 19:588-594. https: //doi.org/10.1016/j.idairyj.2009.04.008.

Costa, J. H. C., M. A. G. von Keyserlingk, and D. M. Weary. 2016. Invited review: Effects of group housing of dairy calves on behavior, cognition, performance, and health. J. Dairy Sci. 99:2453-2467. https://doi.org/10.3168/jds.2015-10144.

Coulon, J.-B., A. Delacroix-Buchet, B. Martin, and A. Pirisi. 2004. Relationships between ruminant management and sensory characteristics of cheeses: A review. Lait 84:221-241. https://doi.org/10 .1051/lait:2004008.

Couvreur, S., C. Hurtaud, C. Lopez, L. Delaby, and J.-L. Peyraud. 2006. The linear relationship between the proportion of fresh grass in the cow diet, milk fatty acid composition, and butter properties. J. Dairy Sci. 89:1956-1969. https://doi.org/10.3168/jds.S0022 $-0302(06) 72263-9$.

Craig, W. J. 2009. Health effects of vegan diets. Am. J. Clin. Nutr. 89:1627S-1633S. https://doi.org/10.3945/ajcn.2009.26736N.

Dairy Australia. 2020. Situation and Outlook Reports December 2020. Accessed Jan. 2021. https://www.dairyaustralia.com.au/resource -repository/2020/12/08/situation-and-outlook-report-december -2020\#.YASuZOdxeUk.

Dawkins, M. S. 2004. Using behaviour to assess animal welfare. Anim. Welf. 13:3-7.

de Klein, C. A. M., and R. J. Eckard. 2008. Targeted technologies for nitrous oxide abatement from animal agriculture. Aust. J. Exp. Agric. 48:14-20. https://doi.org/10.1071/EA07217.

de Kruif, C. G., T. Huppertz, V. S. Urban, and A. V. Petukhov. 2012. Casein micelles and their internal structure. Adv. Colloid Interface Sci. 171-172:36-52. https://doi.org/10.1016/j.cis.2012.01.002.

de la Torre, S., F. Vicente, and L. Royo. 2018. Dairy cows eating grass produce milk with a higher proportion of fat-soluble antioxidants. Pages 443-445 in Sustainable Meat and Milk Production From Grasslands, Proc. 27th General Meeting of the European Grassland Federation, Cork, Ireland. Teagasc, Animal \& Grassland Research and Innovation Centre, Fermoy.

Dharma, S., W. Shafron, and M. Oliver. 2012. Australian dairy: Farm technology and management practices, 2010-11. ABARES Canberra.

Dhiman, T. R., G. R. Anand, L. D. Satter, and M. W. Pariza. 1999. Conjugated linoleic acid content of milk from cows fed different diets. J. Dairy Sci. 82:2146-2156. https://doi.org/10.3168/jds.S0022 -0302(99)75458-5.

Dillon, P., S. Crosse, and B. O'Brien. 1997. Effect of concentrate supplementation of grazing dairy cows in early lactation on milk production and milk processing quality. Ir. J. Agric. Food Res. $36: 145-159$

Dobson, H., and R. F. Smith. 2000. What is stress, and how does it affect reproduction? Anim. Reprod. Sci. 60-61:743-752. https:// doi.org/10.1016/S0378-4320(00)00080-4.

Elgersma, A. 2015. Grazing increases the unsaturated fatty acid concentration of milk from grass-fed cows: A review of the contributing factors, challenges and future perspectives. Eur. J. Lipid Sci. Technol. 117:1345-1369. https://doi.org/10.1002/ejlt.201400469.

Ellis, K. A., K. Billington, B. McNeil, and D. E. F. McKeegan. 2009. Public opinion on UK milk marketing and dairy cow welfare. Anim. Welf. 18:267-282.

European Food Safety Authority. 2009. Scientific report on the effects of farming systems on dairy cow welfare and disease. EFSA J. https://doi.org/10.2903/j.efsa.2009.1143r.

Eurostat. 2019. Agriculture, forestry and fishery statistics. 2019 ed. Statistical Books. Publications office of the European Union. Accessed Apr. 2021. https://ec.europa.eu/eurostat/documents/ 
3217494/10317767/KS-FK-19-001-EN-N.pdf/742d3fd2-961e-68c1 $-47 \mathrm{~d} 0-11 \mathrm{cf} 30 \mathrm{~b} 11489 ? \mathrm{t}=1576657490000$.

FAO. 2019. OECD-FAO Agricultural Outlook 2019-2028. Accessed Jan. 2021. https://www.oecd-ilibrary.org/agriculture-and-food/ oecd-fao-agricultural-outlook-2019-2028_agr_outlook-2019-en.

Faulkner, H., T. F. O'Callaghan, S. McAuliffe, D. Hennessy, C. Stanton, M. G. O'Sullivan, J. P. Kerry, and K. N. Kilcawley. 2018. Effect of different forage types on the volatile and sensory properties of bovine milk. J. Dairy Sci. 101:1034-1047. https://doi.org/10 $.3168 /$ jds.2017-13141.

Fenelon, M. A., and T. P. Guinee. 1999. The effect of milk fat on cheddar cheese yield and its prediction, using modifications of the Van Slyke cheese yield formula. J. Dairy Sci. 82:2287-2299. https://doi .org/10.3168/jds.S0022-0302(99)75477-9.

Finneran, E., P. Crosson, P. O'Kiely, L. Shalloo, P. D. Forristal, and M. Wallace. 2012. Economic modelling of an integrated grazed and conserved perennial ryegrass forage production system. Grass Forage Sci. 67:162-176. https://doi.org/10.1111/j.1365-2494.2011 $.00832 . x$.

Fleming, A. E., G. R. Edwards, R. H. Bryant, D. E. Dalley, and P. Gregorini. 2018. Milk production and milk fatty acid composition of grazing dairy cows supplemented with fodder beet. New Zealand J. Anim. Sci. Prod. 78:6-10.

Fonterra. 2020. Grass fed. Accessed Jan. 2021. https://www.fonterra .com/nz/en/our-co-operative/the-way-we-farm/grass-fed.html.

Fox, P. F. 2003. Milk proteins: General and historical aspects. Pages 1-48 in Advanced Dairy Chemistry - 1 Proteins: Part A/Part B. P. F. Fox and P. L. H. McSweeney, ed. Springer.

Fox, P. F., T. Uniacke-Lowe, P. L. H. McSweeney, and J. A. O'Mahony. 2015. Dairy Chemistry and Biochemistry. 2nd ed. Springer International Publishing.

Frétin, M., B. Martin, S. Buchin, B. Desserre, R. Lavigne, E. Tixier, C. Cirié, C. Bord, M.-C. Montel, C. Delbès, and A. Ferlay. 2019. Milk fat composition modifies the texture and appearance of Cantaltype cheeses but not their flavor. J. Dairy Sci. 102:1131-1143. https://doi.org/10.3168/jds.2018-15534.

Garvey, E. C., T. Sander, T. F. O'Callaghan, M. Drake, S. Fox, M. G. O'Sullivan, J. P. Kerry, and K. N. Kilcawley. 2020. A crosscultural evaluation of liking and perception of salted butter produced from different feed systems. Foods 9:1767. https://doi.org/ 10.3390/foods9121767.

Gaucheron, F. 2005. The minerals of milk. Reprod. Nutr. Dev. 45:473483. https://doi.org/10.1051/rnd:2005030.

Gulati, A., N. Galvin, E. Lewis, D. Hennessy, M. O'Donovan, J. J. McManus, M. A. Fenelon, and T. P. Guinee. 2018. Outdoor grazing of dairy cows on pasture versus indoor feeding on total mixed ration: Effects on gross composition and mineral content of milk during lactation. J. Dairy Sci. 101:2710-2723. https://doi.org/10 .3168 /jds.2017-13338.

Gulati, A., D. Hennessy, M. O'Donovan, J. J. McManus, M. A. Fenelon, and T. P. Guinee. 2019. Dairy cow feeding system alters the characteristics of low-heat skim milk powder and processability of reconstituted skim milk. J. Dairy Sci. 102:8630-8647. https://doi .org/10.3168/jds.2018-15884.

Haas, R., A. Schnepps, A. Pichler, and O. Meixner. 2019. Cow milk versus plant-based milk substitutes: A comparison of product image and motivational structure of consumption. Sustainability 11:5046. https://doi.org/10.3390/su11185046.

Hanrahan, L., N. McHugh, T. Hennessy, B. Moran, R. Kearney, M. Wallace, and L. Shalloo. 2018. Factors associated with profitability in pasture-based systems of milk production. J. Dairy Sci. 101:5474-5485. https://doi.org/10.3168/jds.2017-13223.

Haque, E., and R. Chand. 2008. Antihypertensive and antimicrobial bioactive peptides from milk proteins. Eur. Food Res. Technol. 227:7-15. https://doi.org/10.1007/s00217-007-0689-6.

Harty, M. A., P. J. Forrestal, C. J. Watson, K. L. McGeough, R. Carolan, C. Elliot, D. Krol, R. J. Laughlin, K. G. Richards, and G. J. Lanigan. 2016. Reducing nitrous oxide emissions by changing $\mathrm{N}$ fertiliser use from calcium ammonium nitrate (CAN) to urea based formulations. Sci. Total Environ. 563-564:576-586. https:// doi.org/10.1016/j.scitotenv.2016.04.120.
Haug, A., A. T. Høstmark, and O. M. Harstad. 2007. Bovine milk in human nutrition-A review. Lipids Health Dis. 6:25. https://doi .org/10.1186/1476-511X-6-25.

Heck, J. M. L., A. Schennink, H. J. F. van Valenberg, H. Bovenhuis, M. H. P. W. Visker, J. A. M. van Arendonk, and A. C. M. van Hooijdonk. 2009. Effects of milk protein variants on the protein composition of bovine milk. J. Dairy Sci. 92:1192-1202. https:// doi.org/10.3168/jds.2008-1208.

Heerwagen, L. R., T. Christensen, and P. Sandøe. 2013. The prospect of market-driven improvements in animal welfare: Lessons from the case of grass milk in Denmark. Animals (Basel) 3:499-512. https://doi.org/10.3390/ani3020499.

Hennessy, D., L. Delaby, A. van den Pol-van Dasselaar, and L. Shalloo. 2020. Increasing grazing in dairy cow milk production systems in Europe. Sustainability 12:2443.

Hernandez-Mendo, O., M. A. G. von Keyserlingk, D. M. Veira, and D. M. Weary. 2007. Effects of pasture on lameness in dairy cows. J. Dairy Sci. 90:1209-1214. https://doi.org/10.3168/jds.S0022 -0302(07)71608-9.

Huebsch, M., B. Horan, P. Blum, K. G. Richards, J. Grant, and O. Fenton. 2013. Impact of agronomic practices of an intensive dairy farm on nitrogen concentrations in a karst aquifer in Ireland. Agric. Ecosyst. Environ. 179:187-199. https://doi.org/10.1016/j.agee 2013.08.021.

Hurtado-Uria, C., D. Hennessy, L. Shalloo, D. O'Connor, and L. Delaby. 2013. Relationships between meteorological data and grass growth over time in the south of Ireland. Ir. Geogr. 46:175-201. https://doi.org/10.1080/00750778.2013.865364.

ICBF. 2020. National Calving Trends Update. Bandon, Ireland. Accessed Jan. 2021. https://www.icbf.com/wp-content/uploads/ 2020/10/Dairy-Calving-Stats-PDF-1.pdf.

Jacobs, J. 2014. Challenges in ration formulation in pasture-based milk production systems. Anim. Prod. Sci. 54:1130-1140. https://doi .org/10.1071/AN14463.

Kelley, N. S., N. E. Hubbard, and K. L. Erickson. 2007. Conjugated linoleic acid isomers and cancer. J. Nutr. 137:2599-2607. https:// doi.org/10.1093/jn/137.12.2599.

Kelly, M. L., E. S. Kolver, D. E. Bauman, M. E. Van Amburgh, and L. D. Muller. 1998. Effect of intake of pasture on concentrations of conjugated linoleic acid in milk of lactating cows. J. Dairy Sci. 81:1630-1636. https://doi.org/10.3168/jds.S0022-0302(98)75730 $-3$.

Kelly, P., L. Shalloo, M. Wallace, and P. Dillon. 2020. The Irish dairy industry - Recent history and strategy, current state and future challenges. Int. J. Dairy Technol. 73:309-323. https://doi.org/10 .1111/1471-0307.12682.

Kilcawley, K. N., H. Faulkner, H. J. Clarke, M. G. O'Sullivan, and J. P. Kerry. 2018. Factors influencing the flavour of bovine milk and cheese from grass based versus non-grass based milk production systems. Foods 7:37. https://doi.org/10.3390/foods7030037.

Kitts, D. D., and K. Weiler. 2003. Bioactive proteins and peptides from food sources. Applications of bioprocesses used in isolation and recovery. Curr. Pharm. Des. 9:1309-1323. https://doi.org/10 $.2174 / 1381612033454883$.

Knowles, S. O., N. D. Grace, T. W. Knight, W. C. McNabb, and J. Lee. 2006. Reasons and means for manipulating the micronutrient composition of milk from grazing dairy cattle. Anim. Feed Sci. Technol. 131:154-167. https://doi.org/10.1016/j.anifeedsci.2006 .04 .015 .

Koba, K., and T. Yanagita. 2014. Health benefits of conjugated linoleic acid (CLA). Obes. Res. Clin. Pract. 8:e525-e532. https://doi .org/10.1016/j.orcp.2013.10.001.

Kolver, E. S., and L. D. Muller. 1998. Performance and nutrient intake of high producing Holstein cows consuming pasture or a total mixed ration. J. Dairy Sci. 81:1403-1411. https://doi.org/10.3168/ jds.S0022-0302(98)75704-2.

Korhonen, H., and A. Pihlanto. 2006. Bioactive peptides: Production and functionality. Int. Dairy J. 16:945-960. https://doi.org/10 .1016/j.idairyj.2005.10.012.

Lamarche, B., D. I. Givens, S. Soedamah-Muthu, R. M. Krauss, M. U. Jakobsen, H. A. Bischoff-Ferrari, A. Pan, and J.-P. Després. 2016. 
Does milk consumption contribute to cardiometabolic health and overall diet quality? Can. J. Cardiol. 32:1026-1032. https://doi .org/10.1016/j.cjca.2015.12.033.

Ledgard, S., R. Schils, J. Eriksen, and J. Luo. 2009. Environmental impacts of grazed clover/grass pastures. Ir. J. Agric. Food Res. 48:209-226.

Ledgard, S. F., J. R. Crush, and J. W. Penno. 1998. Environmental impacts of different nitrogen inputs on dairy farms and implications for the Resource Management Act of New Zealand. Environ. Pollut. 102(Suppl. 1):515-519. https://doi.org/10.1016/S0269 $-7491(98) 80077-8$.

Lee, B.-H., M. Corazzin, E. Piasentier, C.-S. Huh, K.-I. Sung, and S.Y. Park. 2019. Milk and Montasio-type cheese fatty acid composition from cows grazing on timothy and reed canarygrass pasture or fed indoor. Grassl. Sci. 65:226-232. https://doi.org/10.1111/ grs. 12239 .

Legrand, A. L., M. A. G. von Keyserlingk, and D. M. Weary. 2009. Preference and usage of pasture versus free-stall housing by lactating dairy cattle. J. Dairy Sci. 92:3651-3658. https://doi.org/10 $.3168 /$ jds.2008-1733.

Leip, A., F. Weiss, T. Wassenaar, I. Perez, T. Fellmann, P. Loudjani, F. Tubiello, D. Grandgirard, S. Monni, and K. Biala. 2010. Evaluation of the livestock sector's contribution to the EU greenhouse gas emissions (GGELS) - Final report. EU Publications Office. https:/ /op.europa.eu/en/publication-detail/-/publication/38abd8e0-9fe1 -4870-81da-2455f9fd75ad.

Linn, J. G. 1988. Factors affecting the composition of milk from dairy cows. Pages 224-241 in Designing Foods: Animal Product Options in the Marketplace. National Academics Press.

Liu, N., A. M. Pustjens, S. W. Erasmus, Y. Yang, K. Hettinga, and S. M. van Ruth. 2020. Dairy farming system markers: The correlation of forage and milk fatty acid profiles from organic, pasture and conventional systems in the Netherlands. Food Chem. 314:126153. https://doi.org/10.1016/j.foodchem.2019.126153.

Lovegrove, J. A., and D. I. Givens. 2016. Dairy food products: Good or bad for cardiometabolic disease? Nutr. Res. Rev. 29:249-267. https://doi.org/10.1017/S0954422416000160.

Lucas, A., C. Agabriel, B. Martin, A. Ferlay, I. Verdier-Metz, J.-B. Coulon, and E. Rock. 2006. Relationships between the conditions of cow's milk production and the contents of components of nutritional interest in raw milk farmhouse cheese. Lait 86:177-202. https://doi.org/10.1051/lait:2005049.

Lucas, A., D. Andueza, A. Ferlay, and B. Martin. 2008a. Prediction of fatty acid composition of fresh and freeze-dried cheeses by visible near-infrared reflectance spectroscopy. Int. Dairy J. 18:595-604. https://doi.org/10.1016/j.idairyj.2007.12.001.

Lucas, A., D. Andueza, E. Rock, and B. Martin. 2008b. Prediction of dry matter, fat, $\mathrm{pH}$, vitamins, minerals, carotenoids, total antioxidant capacity, and color in fresh and freeze-dried cheeses by visible-near-infrared reflectance spectroscopy. J. Agric. Food Chem. 56:6801-6808. https://doi.org/10.1021/jf800615a.

Mackle, T. R., A. M. Bryant, S. F. Petch, R. J. Hooper, and M. J. Auldist. 1999. Variation in the composition of milk protein from pasture-fed dairy cows in late lactation and the effect of grain and silage supplementation. N. Z. J. Agric. Res. 42:147-154. https:// doi.org/10.1080/00288233.1999.9513364.

Magan, J. B., J. T. Tobin, T. F. O'Callaghan, A. L. Kelly, M. A. Fenelon, D. Hennessy, and N. A. McCarthy. 2019. Physicochemical properties of whole milk powder derived from cows fed pasture or total mixed ration diets. J. Dairy Sci. 102:9611-9621. https://doi .org/10.3168/jds.2019-16415.

McAuliffe, S., T. J. Gilliland, M. Egan, and D. Hennessy. 2016. Comparison of pasture based feeding systems and a total mixed ration feeding system on dairy cow milk production. Pages 376-378 in The Multiple Roles of Grassland in the European Bioeconomy, Proc. 26th General Meeting of the European Grassland Federation, Trondheim, Norway. NIBIO.

McCarthy, B., L. Delaby, K. Pierce, F. Journot, and B. Horan. 2011. Meta-analysis of the impact of stocking rate on the productivity of pasture-based milk production systems. Animal 5:784-794. https:/ /doi.org/10.1017/S1751731110002314.
McEvoy, M., E. Kennedy, J. P. Murphy, T. M. Boland, L. Delaby, and M. O'Donovan. 2008. The effect of herbage allowance and concentrate supplementation on milk production performance and dry matter intake of spring-calving dairy cows in early lactation. J. Dairy Sci. 91:1258-1269. https://doi.org/10.3168/jds.2007-0710.

McKay, Z. C., M. B. Lynch, F. J. Mulligan, G. Rajauria, C. Miller, and K. M. Pierce. 2019. The effect of concentrate supplementation type on milk production, dry matter intake, rumen fermentation, and nitrogen excretion in late-lactation, spring-calving grazing dairy cows. J. Dairy Sci. 102:5042-5053. https://doi.org/10.3168/ jds.2018-15796.

Mehta, B. M. 2015. Chemical composition of milk and milk products. Pages 511-553 in Handbook of Food Chemistry. P. C. K. Cheung and B. M. Mehta, ed. Springer.

Miglior, F., A. Fleming, F. Malchiodi, L. F. Brito, P. Martin, and C. F. Baes. 2017. A 100-Year Review: Identification and genetic selection of economically important traits in dairy cattle. J. Dairy Sci. 100:10251-10271. https://doi.org/10.3168/jds.2017-12968.

Miller, G. D., and N. Auestad. 2013. Towards a sustainable dairy sector: Leadership in sustainable nutrition. Int. J. Dairy Technol. 66:307-316. https://doi.org/10.1111/1471-0307.12067.

Mohammed, R., C. S. Stanton, J. J. Kennelly, J. K. G. Kramer, J. F. Mee, D. R. Glimm, M. O'Donovan, and J. J. Murphy. 2009. Grazing cows are more efficient than zero-grazed and grass silage-fed cows in milk rumenic acid production. J. Dairy Sci. 92:3874-3893. https://doi.org/10.3168/jds.2008-1613.

Moran, J. 2005. Diet and milk production. Pages 159-170 in Tropical Dairy Farming: Feeding Management for Small Holder Dairy Farmers in the Humid Tropics. Landlinks Press.

Murphy, E., I. J. M. de Boer, C. E. van Middelaar, N. M. Holden, L. Shalloo, T. P. Curran, and J. Upton. 2017. Water footprinting of dairy farming in Ireland. J. Clean. Prod. 140:547-555. https://doi .org/10.1016/j.jclepro.2016.07.199.

Nozière, P., B. Graulet, A. Lucas, B. Martin, P. Grolier, and M. Doreau. 2006. Carotenoids for ruminants: From forages to dairy products. Anim. Feed Sci. Technol. 131:418-450. https://doi.org/ 10.1016/j.anifeedsci.2006.06.018.

O'Brien, B., P. Dillon, J. J. Murphy, R. K. Mehra, T. P. Guinee, J. F. Connolly, A. Kelly, and P. Joyce. 1999a. Effects of stocking density and concentrate supplementation of grazing dairy cows on milk production, composition and processing characteristics. J. Dairy Res. 66:165-176. https://doi.org/10.1017/S0022029999003544.

O'Brien, B., and D. Hennessy. 2017. Scientific appraisal of the Irish grass-based milk production system as a sustainable source of premium quality milk and dairy products. Ir. J. Agric. Food Res. 56:120-129. https://doi.org/10.1515/ijafr-2017-0011.

O'Brien, B., R. Mehra, J. F. Connolly, and D. Harrington. 1999b. Seasonal variation in the composition of Irish manufacturing and retail milks: 1 . Chemical composition and renneting properties. Ir. J. Agric. Food Res. 38:53-64.

O'Brien, B., R. Mehra, J. F. Connolly, and D. Harrington. 1999c. Seasonal variation in the composition of Irish manufacturing and retail milks: 4. Minerals and trace elements. Ir. J. Agric. Food Res. 38:87-99.

O'Brien, D., B. Moran, and L. Shalloo. 2018. A national methodology to quantify the diet of grazing dairy cows. J. Dairy Sci. 101:85958604. https://doi.org/10.3168/jds.2017-13604.

O'Brien, D., L. Shalloo, J. Patton, F. Buckley, C. Grainger, and M. Wallace. 2012. Evaluation of the effect of accounting method, IPCC v. LCA, on grass-based and confinement dairy systems greenhouse gas emissions. Animal 6:1512-1527. https://doi.org/10 .1017/S1751731112000316.

O'Callaghan, T. F., H. Faulkner, S. McAuliffe, M. G. O'Sullivan, D. Hennessy, P. Dillon, K. N. Kilcawley, C. Stanton, and R. P. Ross. 2016a. Quality characteristics, chemical composition, and sensory properties of butter from cows on pasture versus indoor feeding systems. J. Dairy Sci. 99:9441-9460. https://doi.org/10.3168/jds .2016-11271.

O'Callaghan, T. F., D. Hennessy, S. McAuliffe, K. N. Kilcawley, M. O'Donovan, P. Dillon. R. P. Ross, and C. Stanton. 2016b. Effect of pasture versus indoor feeding systems on raw milk composition 
and quality over an entire lactation. J. Dairy Sci. 99:9424-9440. https://doi.org/10.3168/jds.2016-10985.

O'Callaghan, T. F., D. Mannion, D. Apopei, N. A. McCarthy, S. A. Hogan, K. N. Kilcawley, and M. Egan. 2019. Influence of supplemental feed choice for pasture-based cows on the fatty acid and volatile profile of milk. Foods 8:137. https://doi.org/10.3390/ foods 8040137 .

O'Callaghan, T. F., D. T. Mannion, D. Hennessy, S. McAuliffe, M. G. O'Sullivan, N. Leeuwendaal, T. P. Beresford, P. Dillon, K. N. Kilcawley, J. J. Sheehan, R. P. Ross, and C. Stanton. 2017. Effect of pasture versus indoor feeding systems on quality characteristics, nutritional composition, and sensory and volatile properties of fullfat Cheddar cheese. J. Dairy Sci. 100:6053-6073. https://doi.org/ $10.3168 /$ jds.2016-12508.

O'Callaghan, T. F., R. Vázquez-Fresno, A. Serra-Cayuela, E. Dong, R. Mandal, D. Hennessy, S. McAuliffe, P. Dillon, D. S. Wishart, C. Stanton, and R. P. Ross. 2018. Pasture feeding changes the bovine rumen and milk metabolome. Metabolites 8:27. https://doi.org/10 $.3390 /$ metabo8020027.

O'Connor, A. H., E. A. M. Bokkers, I. J. M. de Boer, H. Hogeveen, R. Sayers, N. Byrne, E. Ruelle, B. Engel, and L. Shalloo. 2020. Cow and herd-level risk factors associated with mobility scores in pasture-based dairy cows. Prev. Vet. Med. 181:105077. https://doi .org/10.1016/j.prevetmed.2020.105077.

O'Connor, A. H., E. A. M. Bokkers, I. J. M. de Boer, H. Hogeveen, R. Sayers, N. Byrne, E. Ruelle, and L. Shalloo. 2019. Associating cow characteristics with mobility scores in pasture-based dairy cows. J. Dairy Sci. 102:8332-8342. https://doi.org/10.3168/jds.2018-15719.

O'Neill, B. F., M. H. Deighton, B. M. O'Loughlin, F. J. Mulligan, T. M. Boland, M. O'Donovan, and E. Lewis. 2011. Effects of a perennial ryegrass diet or total mixed ration diet offered to springcalving Holstein-Friesian dairy cows on methane emissions, dry matter intake, and milk production. J. Dairy Sci. 94:1941-1951. https://doi.org/10.3168/jds.2010-3361.

O'Sullivan, R., F. J. Monahan, B. Bahar, L. Kirwan, K. Pierce, A. O'Shea, S. McElroy, F. Malone, B. Hanafin, S. Molloy, A. C. O. Evans, and O. Schmidt. 2021. Stable isotope profile (C, N, O, S) of Irish raw milk: Baseline data for authentication. Food Control 121:107643. https://doi.org/10.1016/j.foodcont.2020.107643.

OECD-FAO. 2019. OECD-FAO Agricultural Outlook 2019-2028. Organisation for Economic Co-operation Development-Food and Agriculture Organization of the United Nations.

Oliveira, R., M. Faria, R. Silva, L. Bezerra, G. Carvalho, A. Pinheiro, J. Simionato, and A. Leão. 2015. Fatty acid profile of milk and cheese from dairy cows supplemented a diet with palm kernel cake. Molecules 20:15434-15448. https://doi.org/10.3390/ molecules200815434.

Olmos, G., L. Boyle, A. Hanlon, J. Patton, J. J. Murphy, and J. F. Mee. 2009a. Hoof disorders, locomotion ability and lying times of cubicle-housed compared to pasture-based dairy cows. Livest. Sci. 125:199-207. https://doi.org/10.1016/j.livsci.2009.04.009.

Olmos, G., J. F. Mee, A. Hanlon, J. Patton, J. J. Murphy, and L. Boyle. 2009b. Peripartum health and welfare of Holstein-Friesian cows in a confinement-TMR system compared to a pasture-based system. Anim. Welf. 18:467-476.

Palmquist, D. 2006. Milk fat: Origin of fatty acids and influence of nutritional factors thereon. Pages 43-92 in Advanced Dairy Chemistry. Volume 2. Lipids. Springer.

Palmquist, D. L. 2009. Omega-3 fatty acids in metabolism, health, and nutrition and for modified animal product foods. Prof. Anim. Sci. 25:207-249. https://doi.org/10.15232/S1080-7446(15)30713-0.

Panthi, R. R., A. L. Kelly, D. Hennessy, M. G. O'Sullivan, K. N. Kilcawley, D. T. Mannion, M. A. Fenelon, and J. J. Sheehan. 2019a. Effect of pasture versus indoor feeding regimes on the yield, composition, ripening and sensory characteristics of Maasdam cheese. Int. J. Dairy Technol. 72:435-446. https://doi.org/10 $.1111 / 1471-0307.12590$

Panthi, R. R., U. K. Sundekilde, A. L. Kelly, D. Hennessy, K. N. Kilcawley, D. T. Mannion, M. A. Fenelon, and J. J. Sheehan. 2019b. Influence of herd diet on the metabolome of Maasdam cheeses. Food Res. Int. 123:722-731. https://doi.org/10.1016/j .foodres.2019.05.026.

Patterson, E., R. Wall, G. F. Fitzgerald, R. P. Ross, and C. Stanton. 2012. Health implications of high dietary omega- 6 polyunsaturated fatty acids. J. Nutr. Metab. 2012:539426. https://doi.org/10.1155/ $2012 / 539426$.

Pfeuffer, M., and J. Schrezenmeir. 2000. Bioactive substances in milk with properties decreasing risk of cardiovascular diseases Br. J. Nutr. 84(Suppl. 1):S155-S159. https://doi.org/10.1017/ S0007114500002385.

Pfister, S., A. Koehler, and S. Hellweg. 2009. Assessing the environmental impacts of freshwater consumption in LCA. Environ. Sci. Technol. 43:4098-4104. https://doi.org/10.1021/es802423e.

Pintus, S., E. Murru, G. Carta, L. Cordeddu, B. Batetta, S. Accossu, D. Pistis, S. Uda, M. Elena Ghiani, M. Mele, P. Secchiari, G Almerighi, P. Pintus, and S. Banni. 2013. Sheep cheese naturally enriched in $\alpha$-linolenic, conjugated linoleic and vaccenic acids improves the lipid profile and reduces anandamide in the plasma of hypercholesterolaemic subjects. Br. J. Nutr. 109:1453-1462. https: //doi.org/10.1017/S0007114512003224.

Pustjens, A. M., R. Boerrigter-Eenling, A. H. Koot, M. Rozijn, and S. M. van Ruth. 2017. Characterization of retail conventional, organic, and grass full-fat butters by their fat contents, free fatty acid contents, and triglyceride and fatty acid profiling. Foods 6:26. https://doi.org/10.3390/foods6040026.

Rice, P., D. O'Brien, L. Shalloo, and N. M. Holden. 2019. Defining a functional unit for dairy production LCA that reflects the transaction between the farmer and the dairy processor. Int. J. Life Cycle Assess. 24:642-653. https://doi.org/10.1007/s11367-018-1486-0.

Roche, J. R. 2007. Milk production responses to pre- and postcalving dry matter intake in grazing dairy cows. Livest. Sci. 110:12-24. https://doi.org/10.1016/j.livsci.2006.08.016.

Schingoethe, D. J. 2017. A 100-year review: Total mixed ration feeding of dairy cows. J. Dairy Sci. 100:10143-10150. https://doi.org/10 $.3168 /$ jds.2017-12967.

Schlimme, E., and H. Meisel. 1995. Bioactive peptides derived from milk proteins. Structural, physiological and analytical aspects. Food/Nahrung 39:1-20.

Séverin, S., and X. Wenshui. 2005. Milk biologically active components as nutraceuticals. Crit. Rev. Food Sci. Nutr. 45:645-656. https:// doi.org/10.1080/10408690490911756.

Shalloo, L., A. Cromie, and N. McHugh. 2014. Effect of fertility on the economics of pasture-based dairy systems. Animal 8:222-231.

Shalloo, L., B. Moran, and D. O'Brien. 2018. Define and verify pasture base-How does Irish "pasture fed" compare to the world? Pages 1-6 in Proceedings of the Grass-Fed Dairy Conference 2018. Naas, Co. Kildare, Ireland.

Shortall, O. 2019. Cows eat grass, don't they? Contrasting sociotechnical imaginaries of the role of grazing in the UK and Irish dairy sectors. J. Rural Stud. 72:45-57. https://doi.org/10.1016/j.jrurstud 2019.10.004.

Siri-Tarino, P. W., S. Chiu, N. Bergeron, and R. M. Krauss. 2015. Saturated fats versus polyunsaturated fats versus carbohydrates for cardiovascular disease prevention and treatment. Annu. Rev. Nutr. 35:517-543. https://doi.org/10.1146/annurev-nutr-071714-034449.

Slots, T., G. Butler, C. Leifert, T. Kristensen, L. H. Skibsted, and J. H. Nielsen. 2009. Potentials to differentiate milk composition by different feeding strategies. J. Dairy Sci. 92:2057-2066. https://doi .org/10.3168/jds.2008-1392.

Spitsberg, V. L. 2005. Invited review: Bovine milk fat globule membrane as a potential nutraceutical. J. Dairy Sci. 88:2289-2294. https://doi.org/10.3168/jds.S0022-0302(05)72906-4.

Stampa, E., C. Schipmann-Schwarze, and U. Hamm. 2020. Consumer perceptions, preferences, and behavior regarding pasture-raised livestock products: A review. Food Qual. Prefer. 82:103872. https: //doi.org/10.1016/j.foodqual.2020.103872.

Stanton, C., F. Lawless, G. Kjellmer, D. Harrington, R. Devery, J F. Connolly, and J. Murphy. 1997. Dietary influences on bovine milk cis-9,trans-11-conjugated linoleic acid content. J. Food Sci. 62:1083-1086. https://doi.org/10.1111/j.1365-2621.1997.tb15043 
Sundekilde, U. K., L. B. Larsen, and H. C. Bertram. 2013. NMRbased milk metabolomics. Metabolites 3:204-222. https://doi.org/ 10.3390/metabo3020204.

Swanson, D., R. Block, and S. A. Mousa. 2012. Omega-3 fatty acids EPA and DHA: Health benefits throughout life. Adv. Nutr. 3:1-7. https://doi.org/10.3945/an.111.000893.

Synlait. 2015. Synlait announces new partnership and premium earning milk supply opportunity. Accessed Jan. 2021. https:// www.synlait.com/news/synlait-announces-new-partnership-and -premium-earning-milk-supply-opportunity/.

Thorning, T. K., A. Raben, T. Tholstrup, S. S. Soedamah-Muthu, I. Givens, and A. Astrup. 2016. Milk and dairy products: Good or bad for human health? An assessment of the totality of scientific evidence. Food Nutr. Res. 60:32527. https://doi.org/10.3402/fnr .v60.32527.

Tornambé, G., A. Cornu, P. Pradel, N. Kondjoyan, A. P. Carnat, M. Petit, and B. Martin. 2006. Changes in terpene content in milk from pasture-fed cows. J. Dairy Sci. 89:2309-2319. https://doi .org/10.3168/jds.S0022-0302(06)72302-5.

Toso, B., G. Procida, and B. Stefanon. 2002. Determination of volatile compounds in cows' milk using headspace GC-MS. J. Dairy Res. 69:569-577. https://doi.org/10.1017/S0022029902005782.

Tsioulpas, A., M. J. Lewis, and A. S. Grandison. 2007. Effect of minerals on casein micelle stability of cows' milk. J. Dairy Res. 74:167173. https://doi.org/10.1017/S0022029906002330.

Ulbricht, T. L. V., and D. A. T. Southgate. 1991. Coronary heart disease: Seven dietary factors. Lancet 338:985-992. https://doi.org/ 10.1016/0140-6736(91)91846-M.

USC Title 7. 2011. USC Title 7-Agriculture Chapter 64-Agricultural Research, Extension, and Teaching. US Government Publishing Office.

Valenti, B., B. Martin, D. Andueza, C. Leroux, C. Labonne, F. Lahalle, H. Larroque, P. Brunschwig, C. Lecomte, M. Brochard, and A. Ferlay. 2013. Infrared spectroscopic methods for the discrimination of cows' milk according to the feeding system, cow breed and altitude of the dairy farm. Int. Dairy J. 32:26-32. https://doi.org/ 10.1016/j.idairyj.2013.02.014

Vargas-Bello-Pérez, E., R. I. Márquez-Hernández, and L. E. Hernández-Castellano. 2019. Bioactive peptides from milk: Animal determinants and their implications in human health. J. Dairy Res. 86:136-144. https://doi.org/10.1017/S0022029919000384.

Vasseur, E. 2017. Animal behavior and well-being symposium: Optimizing outcome measures of welfare in dairy cattle assessment. J. Anim. Sci. 95:1365-1371. https://doi.org/10.2527/jas2016.0880.

Veiga, M., A. Botana, L. González, C. Resch-Zafra, S. Pereira-Crespo, R. Lorenzana, T. Dagnac, B. Fernández-Lorenzo, D. A. PlataReyes, and G. Flores-Calvete. 2018. Milk yield and milk composition characteristics of grazing and all-silage dairy systems. Pages 784-786 in Sustainable Meat and Milk Production From Grasslands, Proc. 27th General Meeting of the European Grassland Fed- eration, Cork, Ireland. Teagasc, Animal \& Grassland Research and Innovation Centre.

Verdier-Metz, I., B. Martin, P. Pradel, H. Albouy, S. Hulin, M.-C. Montel, and J.-B. Coulon. 2005. Effect of grass-silage vs. hay diet on the characteristics of cheese: Interactions with the cheese model. Lait 85:469-480. https://doi.org/10.1051/lait:2005032.

von Borell, E., H. Dobson, and A. Prunier. 2007. Stress, behaviour and reproductive performance in female cattle and pigs. Horm. Behav. 52:130-138. https://doi.org/10.1016/j.yhbeh.2007.03.014.

von Keyserlingk, M. A. G., J. Rushen, A. M. de Passillé, and D. M. Weary. 2009. Invited review: The welfare of dairy cattle - Key concepts and the role of science. J. Dairy Sci. 92:4101-4111. https:// doi.org/10.3168/jds.2009-2326.

Wales, W., and E. Kolver. 2017a. Challenges of feeding dairy cows in Australia and New Zealand. Anim. Prod. Sci. 57:1366-1383. https: //doi.org/10.1071/AN16828.

Wales, W. J., and E. S. Kolver. 2017b. Challenges of feeding dairy cows in Australia and New Zealand. Anim. Prod. Sci. 57:13661383. https://doi.org/10.1071/AN16828.

Wall, R., R. P. Ross, G. F. Fitzgerald, and C. Stanton. 2010. Fatty acids from fish: The anti-inflammatory potential of long-chain omega-3 fatty acids. Nutr. Rev. 68:280-289. https://doi.org/10.1111/j .1753-4887.2010.00287.x

Washburn, S. P., S. L. White, J. T. Green Jr., and G. A. Benson. 2002. Reproduction, mastitis, and body condition of seasonally calved Holstein and Jersey cows in confinement or pasture systems. J. Dairy Sci. 85:105-111. https://doi.org/10.3168/jds.S0022 $-0302(02) 74058-7$.

White, S. L., J. A. Bertrand, M. R. Wade, S. P. Washburn, J. T. Green Jr., and T. C. Jenkins. 2001. Comparison of fatty acid content of milk from Jersey and Holstein cows consuming pasture or a total mixed ration. J. Dairy Sci. 84:2295-2301. https://doi.org/10.3168/ jds.S0022-0302(01)74676-0.

Wilkinson, J. M., and M. Lee. 2018. Use of human-edible animal feeds by ruminant livestock. Animal 12:1735-1743. https://doi.org/10 .1017/S175173111700218X.

Yan, M. J., J. Humphreys, and N. M. Holden. 2013. The carbon footprint of pasture-based milk production: Can white clover make a difference? J. Dairy Sci. 96:857-865. https://doi.org/10.3168/jds .2012-5904.

\section{ORCIDS}

Alice Moscovici Joubran (๑ https://orcid.org/0000-0002-2051-0345

Karina M. Pierce @ https://orcid.org/0000-0002-2056-6189

Laurence Shalloo 누 https://orcid.org/0000-0003-1714-672X

Tom F. O'Callaghan @ () https://orcid.org/0000-0003-2684-7253 